\title{
ZUSES
}

soienoe for a changing world

\section{Type Locality for the Great Blue Limestone in the Bingham Nappe, Oquirrh Mountains, Utah}

by Mackenzie Gordon, $\mathrm{Jr}^{1}$, Edwin $\mathrm{W}$. Tooker ${ }^{2}$ and J. Thomas Dutro, Jr. ${ }^{3}$

Open-File Report-OF 00-012

2000

This report is preliminary and has not been reviewed for conformity with U.S. Geological Survey editorial standards or with the North American Stratigraphic Code. Any use of trade, firm, or product names is for descriptive purposes only and does not imply endorsement by the U.S. Government

U.S. DEPARTMENT OF THE INTERIOR

U.S. GEOLOGICAL SURVEY

${ }^{1}$ Deceased, ${ }^{2}$ Menlo Park, CA, and ${ }^{3}$ Washington, D.C. 


\section{TABLE OF CONTENTS}

Page

Abstract. ....................... 4

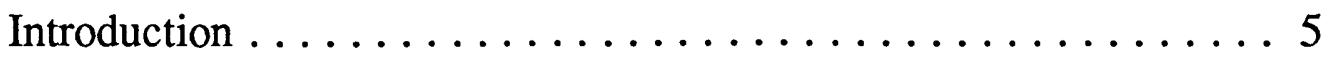

Regional Geologic Setting of the Bingham Nappe . . . . . . . 8

The Type Section of the Great Blue Limestone. . . . . . . . . . 9

Location . . . . . . . . . . . . . . . . . 9

General Lithologic Characteristics of the Great Blue

Limestone . . . . . . . . . . . . . . . . 10

Silveropolis Limestone Member of Tooker and

Gordon, (1978). . . . . . . . . . . . . 11

Long Trail Shale Member. . . . . . . . . . . . 11

Mercur Limestone Member of Tooker and

Gordon (1978). . . . . . . . . . . . . 12

Fossils and Age of the Great Blue Limestone. . . . . . . 14

Regional Lithologic and Faunal Correlations of the Great Blue

Limestone . . . . .................... 16

East Tintic Mountains . . . . . . . . . . . . . 17

Southern Oquirrh Mountains-Fivemile Pass Nappe . . . 18

Northern Oquirrh Mountains-Rogers Canyon Nappe . . .18

Wasatch Mountains-Timpanogos Nappe . . . . . . . . . 19

Wasatch Mountains-Mount Raymond Nappe . . . . . . . 20

Promontory Mountains .................... 21

Other Neighboring Ranges of the Oquirrh Mountains . . . . . . 22

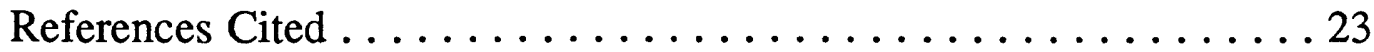

Appendices

1. Type locality of the Great Blue Limestone on

Silveropolis Hill, Ophir mining district, Utah . . . . .26

2. Reference locality, Mercur limestone member,

Great Blue Limestone, Mercur mining district,

Utah 


\section{ILLUSTRATIONS}

FIGURE

1. Index map showing the location of the Bingham, Ophir, and Mercur mining districts in the southern Oquirrh Mountains, Utah . . . . . . . . . . . . . 54

2. Evolution of stratigraphic nomenclature for the

Great Blue Limestone and conformable enclosing formations in the Oquirrh Mountains type locality. ....................... 55

3. Geologic setting in the Bingham nappe in the southern Oquirrh Mountains and the location of the Great Blue Limestone type and reference

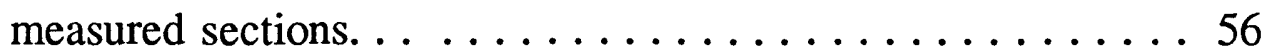

4. Diagrammatic columnar section of the Silveropolis limestone member of the Great Blue Limestone. . . . . . 57

5. Diagrammatic columnar section of the Long Trail Shale Member of the Great Blue Limestone . . . . . . . . . . 58

6. Diagrammatic columnar section of the Mercur limestone member of the Great Blue Limestone. . . . . . 59

7 Diagrammatic columnar section of the Great Blue Limestone showing the location of fossil collections, the faunal zones, and age series represented. . . . . . 60

8. Regional correlations of the age equivalents of the Great Blue Limestone in the Oquirrh Mountains and adjoining mountain ranges $\ldots \ldots \ldots \ldots 1$ 
The type locality for the Great Blue Limestone in the Bingham nappe, Oquirrh Mountains, Utah,

by Mackenzie Gordon, Jr. ${ }^{1}$, Edwin W. Tooker, and J. Thomas Dutro, Jr.

\section{Abstract}

The Great Blue Limestone was named originally by Spurr (1895) from exposures near the Mercur mining district in the Oquirrh Mountains, Utah. The formation was described in greater detail by Gilluly (1932) in the Ophir mining district. Neither formally established a type locality for this formation in the Oquirrh Mountains. However, the formation has since been correlated broadly with similar sedimentary rocks elsewhere in the adjoining Rocky Mountains and Great Basin regions. For the record, and to assist future correlations, a type measured section of the Great Blue Limestone in the Oquirrh Mountains is located, described, and a detailed measured section is included in the appendix.

The Great Blue Limestone consists of three members. The Silveropolis limestone member of Tooker and Gordon (1978), which is the unnamed lower limestone of Gilluly (1932). It is a $260 \mathrm{~m}$ thick stratigraphic section composed of dark-gray, medium-bedded limestone, intercalated with sandstone and argillaceous limestone. This is overlain by the Long Trail Shale, whose type locality Gilluly (1932) specified at the head of Long Trail Gulch in the Ophir mining district. It is $33 \mathrm{~m}$ thick and composed of carbonaceous gray shale and interbedded fossiliferous medium-gray limestone. The Mercur limestone member of Tooker and Gordon (1978), which is Gilluly's (1932) unnamed upper limestone, is $471 \mathrm{~m}$ thick and composed of alternating dark-gray fossiliferous, sandy, and cherty limestones separated by interbedded shale and shaly limestone intervals.

The type locality of the Great Blue Limestone is on the easttrending ridge $1.8 \mathrm{~km}$ south of Ophir (Mercur 7.5-minute

1 Mr. Gordon died before a final draft of this report was completed. 
quadrangle), along a broken line between Silveropolis Hill, the head of Long Trail Gulch, to Hill 8790, and in an offset, $0.6 \mathrm{~km}$ to the southeast, eastward to the South Fork of Ophir Canyon. The formation is $765 \mathrm{~m}$ thick, rests conformably on the Humbug Formation, and is overlain conformably by the Manning Canyon Shale.

The age of the Great Blue Limestone is Late Mississippian. The upper part of the FABEROPHYLLUM Coral Zone, (latest Meramecian), occupies the lower $34 \mathrm{~m}$ of the lower member. Above this, the formation is Chesterian in age. The CANINIA Coral Zone is recorded from $197 \mathrm{~m}$ to $322 \mathrm{~m}$ above the base of the Mercur limestone. The only coral between the two zones is AMPLEXIZAPHRENTES. SPIRIFER BRAZERIANUS Girty appears in the Long Trail Shale and continues upward to at least the top of the CANINIA Zone.

Measurement of the Great Blue Limestone type section permits more systematic comparisons of the stratigraphy of its agecorrelative rocks in the region. The thrust-fault terranes resulting from the Sevier Orogeny (Armstrong, 1968) contain differences in lithologies that represent their deposition in distinct, commonly widely separated hinterland sites (Tooker, 1983). Examples of these differences, which can be seen in foreland thrust nappes now located in the northern Oquirrh, Tintic, Wasatch, Stansbury and Promontory Mountains, underscore the magnitude of regional variations in Great Blue Limestone-age lithologies.

\section{Introduction}

The Great Blue Limestone is of broad regional stratigraphic, sedimentational, and economic significance. It has lithofacies equivalents in a geographic belt from Idaho to Nevada, and age equivalents in Montana, Wyoming, Colorado, and Arizona (Rose, 1976). In spite of this, there is no measured stratigraphic section in its southern Oquirrh Mountains type locality, which lies between the Ophir and Mercur mining districts in the Bingham nappe (Fig. 1). 
Furthermore, the impact of thrust-fault terranes in the Sevier orogenic belt on the regional distribution of the Great Blue Limestone and its correlative formations is not generally recognized. For these reasons, the stratigraphic and paleontologic characteristics of the Great Blue Limestone are detailed here and compared with counterparts in the region. Finally, the upper part of the Silveropolis limestone member of the formation is a favorable stratigraphic site for the occurrence of disseminated gold deposits in the southern Oquirrh Mountains (Kornze and others, 1985) and perhaps elsewhere.

\section{FIGURE 1, NEAR HERE}

The Great Blue Limestone was named and described in general terms by Spurr (1895) for outcrops in the Mercur mining district in the southern part of the Oquirrh Mountains, Utah. He characterized the rocks as comparatively uniform, massive, calcareous limestones of dark-gray color, which he estimated to be about $1,410 \mathrm{~m}$ thick. Its generally uniform character is interrupted by two belts of black carbonaceous and calcareous shales-one situated near the base and the other near the top. Spurr (1895) further recognized that the formation is underlain conformably by a prominent lower intercalated limestone-sandstone sequence. The slope outcrops of the Great Blue Limestone typically are less rugged than the enclosing formational units. Interbedded argillaceous limestone and shale zones in the formation, he noted, are characterized at the surface by bands of heavier foliage, which enhances the typical muted banded appearance of the formation. Spurr's formational terminology and unit thicknesses are shown in Figure 2.

FIGURE 2, NEAR HERE

In his report on the Stockton and Fairfield quadrangles, Utah, Gilluly (1932) modified and formalized Spurr's (1895) stratigraphic terminology (Fig. 2) and split off Spurr's upper shale unit from the Great Blue Limestone, naming it the Manning Canyon Shale. He 
divided the remaining parts of the Great Blue Limestone into the upper and lower limestone members separated by the Long Trail Shale. On the basis of mapping, he estimated the average thicknesses for the member units (Fig. 2). He did not record a measured section but designated a type locality for the Long Trail Shale Member at the head of Long Trail Gulch in the Ophir mining district, which is about $5 \mathrm{~km}$ north of the Mercur district.

In 1962, Mackenzie Gordon, Jr., Helen Duncan, Raymond Lewandowski, and E. W. Tooker measured the type section of the Great Blue Limestone near Ophir, as designated by Gilluly, and made extensive collections of fossils; these are summarized here and listed in Appendix 1. The fossil collections were studied and reported in 1978 and 1979 by the senior author, Helen Duncan, W. J. Sando, O. L. Karklins, B. L. Mamet, and in consultation with J. T. Dutro, Jr., and G. A. Cooper. Subsequentially, in 1980, Gordon and Tooker measured a reference section of the Mercur limestone member, located $1.8 \mathrm{~km}$ north of the Mercur townsite, Mr. Gordon died before the fossil collections were described, and Dutro has studied them, and they are listed in Appendix 2 of this report.

Tooker and Roberts (1970) described a measured stratigraphic section of the Green Ravine Formation, the age-equivalent of the Mercur limestone member in the northern Oquirrh Mountains. They recognized that these rocks are in the Rogers Canyon nappe, a different thrust plate from the Bingham nappe in which the type locality occurs. Gordon and Duncan (1970) collected and listed the fossils in the Green Ravine Formation. More recently, Butkis (1975) considered the regional distribution and physical and deposition characteristics of the Great Blue Limestone in central and northcentral Utah.

Although Tooker is mainly responsible for this report, Gordon's scientific contributions are a major basis for it, and, in recognition of this fact, he is designated with gratitude as senior author. Dutro's contribution is the description and identification of the Mercur 
limestone member fauna in the reference section collected by Gordon and Tooker, which were not completed before Gordon's death. For this important contribution, Dutro becomes a coauthor of this report. A technical review of the report by T. W. Henry, formerly a member of the Branch of Paleontology and Stratigraphy of the U.S. Geological Survey, who is familiar with fossils in this region, is greatly appreciated.

\section{Regional Geologic Setting of the Bingham Nappe}

The Oquirrh Mountains are composed of allochthonous folded and complexly faulted upper Paleozoic sedimentary rocks in five nappes emplaced in the foreland of the Sevier thrust belt during the Late Cretaceous Sevier orogeny (Armstrong, 1968; Roberts and Crittenden, 1973; Tooker, 1983, 1999). These include the earliest arrival, the Pass Canyon nappe, followed in sequence by the Bingham, Rogers Canyon, South Mountain, and Fivemile Pass nappes. The Great Blue Limestone or its temporal equivalents occur in the Bingham, Rogers Canyon, and Fivemile Pass nappes.

The Bingham nappe, which contains the type locality for the Great Blue Limestone, is largest in area and the thickest of the thrust-faulted plates and is exposed in the southern Oquirrh Mountains (Tooker, 1999). The nappe consists of four broad, highamplitude, locally asymmetrical folds, the Ophir anticline along the west side of the range, the Pole Canyon syncline making up the central and eastern parts of the range, and the Long Ridge anticline and Bingham syncline that lie in the northeast part of the nappe. The Great Blue Limestone crops out along the much faulted flanks of the Ophir anticline (Fig. 3) and in the core of the Long Ridge anticline (Tooker, 1999). The basal Midas thrust is not exposed, but several imbricate thrusts in the Bingham nappe that have relatively small amounts of movement are exposed in the range and along the western range front (Tooker and Roberts, 1988). The folds are cut by steeply dipping transcurrent (tear) and normal faults initiated during a compressional orogenic phase and reactivated during the 
later extension of the Basin and Range region (Tooker and Roberts, 1992).

\section{FIGURE 3, NEAR HERE.}

The sedimentary rocks in the Bingham nappe range in age from the Cambrian Tintic Quartzite to the Pennsylvanian Oquirrh Group (Gilluly, 1932; Tooker and Roberts, 1970; and 1998). The Great Blue Limestone lies in the middle of these Paleozoic sedimentary rocks and is in the upper part of the Mississippian carbonate-rich sequence resting conformably on the Humbug Formation. The Great Blue Limestone is overlain conformably by the Manning Canyon Shale (Pennsylvanian-Mississippian). Three members of the Great Blue Limestone recognized by Gilluly (1932) are designated here as the lower Silveropolis limestone of Tooker and Gordon (1978), the medial Long Trail Shale, and the upper Mercur limestone of Tooker and Gordon (1978).

\section{The Type Section of the Great Blue Limestone}

Location

The type measured section of the Great Blue Limestone (Appendix 1) lies about $2 \mathrm{~km}$ south of Ophir, Utah, near the top of the west-facing slope of Silveropolis hill in the NW 1/4, SE 1/4, SE $1 / 4$, sec. 25 , T. 5 S., R. 4 W. (Fig. 3), beginning at about the $8,200 \mathrm{ft}$ (2499 m.) contour. The measured section of the Silveropolis limestone member trends $1.5 \mathrm{~km}$ easterly toward the head of Long Trail Gulch. The Long Trail Shale Member lies in the saddle. The Mercur limestone member extends up the slope of Hill 8790 and continues in an offset upper portion from the crest of the southeasttrending ridge of Hill 8790 at the head of Silverado Canyon northeastward to the South Fork of Ophir Canyon (Fig. 3). Access to the section is by unimproved roads from Ophir, via Long Trail Gulch, or via the South Fork, Ophir Canyon (Mercur 7.5-minute quadrangle). 
A reference measured stratigraphic section (Appendix 2) of the Mercur limestone member is on the hill about $1.5 \mathrm{~km}$ northeast of the Mercur mining district, Utah (Mercur 7.5 minute quadrangle, Utah). The section begins in Meadow Canyon at the contact of the Long Trail Shale at about the $6,800 \mathrm{ft}$ contour in the SW $1 / 4$, NW 1/4, sec. 5, T. 6 S., R. 3 W. (Fig. 3).

The geology of the area was mapped by Gilluly (1932) in the Stockton and Fairfield 15-minute quadrangle, by Tooker (1987) in the Mercur 7.5-minute quadrangle, and in the Oquirrh Mountains by Tooker and Roberts (1998) at the scale of 1:50,000. The stratigraphic sections were measured by tape and Brunton compass, and characteristic fossils were collected.

General Lithologic Characteristics of the Great Blue Limestone

The lithologic details of the stratigraphic sequence in the type and reference localities are available in Appendices 1 and 2, but several collective features of the three members of the Great Blue Limestone provide useful guides for mapping. Although similar in many respects, there are several distinguishing differences between members and their enclosing strata in the Bingham nappe.

The Great Blue Limestone is underlain conformably by the Humbug Formation of Mississippian age; its prominent ledge-andslope topographic expression is the result of alternating sandstone, quartzite, and clastic limestone layers. The Humbug-Great Blue Limestone contact was arbitrarily "placed at the top of the highest considerable group of sandstone beds," Gilluly (1932, p. 29) and represents a transition from a predominantly sandstone to a predominantly limestone lithology. The sedimentary rocks of the Humbug Formation characteristically are brown weathering and throw a distinctive float that contrasts with the blue-gray limestone of the lower massive gray limestone beds of the Silveropolis limestone. 
Silveropolis limestone member of Tooker and Gordon (1978)-

The lower limestone member of Gilluly, (1932), named for the hill on which it was measured, is $260 \mathrm{~m}$ thick, is conformable with the Humbug Formation, and is divided into three typical conformable sedimentary subunits (Fig. 4). A 122 m-thick basal unit consists of thick-bedded to massive interbedded dark-gray, thin-to mediumbedded, locally fossiliferous argillaceous limestone, locally silicified, and $\tan$ to olive-gray, buff-weathering calcareous sandstone or sandy limestone. This subunit, is correlated with the Topliff limestone, which is the lowest member of the Great Blue Formation ${ }^{2}$ at Tintic, Utah (Morris and Lovering, 1961). The middle unit is $97 \mathrm{~m}$ thick and consists of interbedded dark-gray, thin-to-medium-bedded, locally fossiliferous limestone and argillaceous, sandy and cherty limestones. Black chert nodules and lenses occur in the dark-gray limestone beds. The upper unit is $42 \mathrm{~m}$ thick and contains interbedded medium dark-gray, thin-to-medium bedded, locally fossiliferous limestone, argillaceous limestone, calcareous shale and siltstone, finegrained calcareous sandstone, and silty limestone. The subunit characteristically is weathered brownish and tan and generally is abundantly fossiliferous. The middle and upper subunits are correlated with the Paymaster Member at Tintic (Morris and Lovering, 1961). The upper unit may be attenuated here by a fault whose east side is down a small but unknown amount in the type locality (Tooker, 1987).

\section{FIGURE 4, NEAR HERE}

Long Trail Shale-The middle member is at least $33 \mathrm{~m}$ thick, as mapped by Tooker (1987) in the type locality, and apparently is conformable with the lower limestone member. A left-lateral fault, which crosses the measured section in the saddle between Long Trail Gulch and Silverado Canyon (Fig. 3), displaces the southern

2 Morris and Lovering named these rocks the Great Blue Formation in recognition of the predominant thicknesses of shale and quartzite over limestone in the Tintic, Utah, area (Morris, oral commun., 1966). 
continuation of the Great Blue Limestone section a few meters toward the east. Because of the lack of distinctive beds at the contact of the Long Trail Shale, the member was mapped by Gilluly (1932) mainly on the basis of its topographic expression, where it commonly forms a narrow strike valley. This results in some uncertainty about the thickness, which he estimated ranges from 8 to $28 \mathrm{~m}$. It raises the possibility that the imbricate Long Trail thrust(?) locally may cut out parts of the Long Trail Shale along its strike (Tooker and Roberts, 1998). At the type locality, the unit parallels a 17-m thick, sill-like unit of altered granodiorite. No comparable lithology representative of the Long Trail Shale occurs in the Bingham nappe at Tintic (Morris and Lovering, 1961).

The Long Trail Shale consists of interbedded dark-gray to black calcareous and carbonaceous shales, which predominate in the upper part, and thin-bedded, gray, fossiliferous argillaceous limestone and brownish-gray silty limestone in the lower part (Fig. 5). The base of the middle member represents a transition from interbedded sandy limestone, siltstone, and calcareous shale in the Silveropolis limestone member to predominantly silty siliceous limestone, carbonaceous shales and argillaceous, fossiliferous limestones above.

\section{FIGURE 5, NEAR HERE}

Mercur limestone member of Tooker and Gordon (1978)-The upper limestone member of Gilluly (1932), here called the Mercur limestone member for exposures in a reference section (app. 2), which Gordon and Tooker measured on the hill $1.4 \mathrm{~km}$ northeast of Mercur, Utah. It is $481.8 \mathrm{~m}$ thick and apparently conformable with the Long Trail Shale. In its type locality, the member is $470 \mathrm{~m}$ thick.

The type section of the Mercur limestone is composed of four characteristic conformable subunits (Fig. 6). The basal unit is $40 \mathrm{~m}$ thick and consists of banded interbedded limestone, argillaceous limestone, and shale. Calcareous siltstone and light-brownish-gray, thin-to-medium-bedded sandstone layers begin to appear in the 
upper part. Fossils are sparse. The subunit is cut by small, altered porphyry sill- and dike-like bodies in its lower part. The second subunit is $91 \mathrm{~m}$ thick and grades into a zone of platy, medium-gray and light-gray to brownish weathering, partly covered, argillaceous limestone with abundant fossil fragments. The third subunit is 136 $\mathrm{m}$ thick and composed of interbedded medium- to dark-gray, lightto medium-blue-gray weathered limestones separated by thin argillaceous limestone and calcareous shale intervals. Sandy limestone also occurs in the upper part. Locally, the limestone bands contain spheroidal to lenticular siliceous inclusions that weather brownish gray. The upper subunit is $294 \mathrm{~m}$ thick and not well exposed on the dip-slope of the type section. It consists of interbedded medium-gray, fine-grained to silty, thin- to mediumbedded limestone, dark-gray to black, nodular cherty limestone, and sandy, argillaceous, and fossiliferous limestone beds. Argillaceous limestone and calcareous shaly intervals in the unit provide the characteristic banded outcrop pattern that results from more abundant foliage growth in the shale zones.

\section{FIGURE 6, NEAR HERE}

The Great Blue Limestone is overlain conformably by the Manning Canyon Shale (Tooker, 1987), which almost everywhere in the Oquirrh Mountains occurs in a broad strike valley. At the type locality, the Manning Canyon Shale floors the through-going northtrending valley of the South Fork of Ophir Canyon and the adjoining south-trending Manning Canyon. The steep-dipping Manning thrust is inferred to lie in a covered zone along the base of the east-facing slope of the South Fork of Ophir Canyon. Thus, it is possible that the upper limestone member is attenuated. Where exposed, the Manning Canyon Shale is composed of carbonaceous, dark-gray, medium-dark-gray-weathering shale interbedded with thin-bedded gray limestone at the base, a medial brown-weathering quartzite unit and an upper interbedded fossiliferous and argillaceous limestone, thin- to medium-bedded limestone and calcareous shales (Gilluly, 1932; and Tooker, 1987). 
Fossils and Age of the Great Blue Limestone

The age of the Great Blue Limestone is Late Mississippian. Dating of it in the Silveropolis limestone type section is mainly by megafossil identifications in collections by Gordon and Duncan, and of the corals studied by W. J. Sando of the U.S. Geological Survey. Bryozoans were examined by O. L. Karklins, USGS, and the foraminifera by B. L. Mamet of the University of Montreal. Some 31 collections and recollections from this measured section are by the writers, Helen Duncan, and Raymond Lewandowski (Fig. 7). Few species can be identified beyond the generic level in the lists of fossils in Appendices 1 and 2. Either they represent new species, or their preservation is not sufficient to permit specific identification. Preservation seems best in the Silveropolis limestone member.

\section{FIGURE 7, NEAR HERE}

The lower $46 \mathrm{~m}$ contains corals of the FABEROPHYLLUM Zone. These are present in five collections, along with foraminifera of Mamet's zone 15 (Mamet, 1969), which is equivalent to the FABEROPHYLLUM Coral Zone. This zone is the highest of Meramecian age in the Great Basin. The upper part of the FABEROPHYLLUM Coral Zone (latest Meramecian) occupies the lower $46 \mathrm{~m}$ of the lower member. Above this, the formation is Chesterian in age. The CANINIA Coral Zone occurs from 122-294 $\mathrm{m}$ above the base of the lower member. The only coral between the two zones is AMPLEXIZAPHRENTIS. SPIRIFER BRAZERIANUS Girty appears in the Long Trail Shale and continues upward to at least the top of the CANINIA Zone.

The precise level at which Chesterian fossils make their first appearance in the measured section is not determined. The two collections, at 58 and 75-78 $\mathrm{m}$ above the base, respectively, are in the very fine grained limestone, and the fossils, mostly small 
brachiopods and pelecypods, are not diagnostic. The lower collection yielded foraminifera of possible Zone 15 affinity. A 2.8-m thick, bryozoan-bearing limestone, $171 \mathrm{~m}$ above the base, provides the lower occurrence of fossils of undoubted Chesterian age. This unit contains foraminifera of Mamet's Zone 16, which is Chester in age but not earliest Chester. The boundary between the equivalents of these two series, therefore, lies within the lower member of the Great Blue Limestone, and most probably not far above the highest occurrence of FABEROPHYLLUM Zone corals.

The beds immediately below and above these rocks, and in the upper part of the Long Trail Shale contain a fairly large brachiopod fauna. SPIRIFER BRAZERIANUS Girty appears in the Long Trail Shale and continues through much of the formation. The only coral found in this part of the section is the long-ranging AMPLEXIZAPHRENTIS. Above this, the beds contain sparse megafossils.

Another important faunal zone in the Great Blue Limestone, which roughly indicates middle Chesterian age, is commonly known as the CANINIA or $\mathrm{K}$ Zone. The lowest occurrence of these corals is $133 \mathrm{~m}$ above the base of the Mercur limestone and consists solely of fragments. Sando (written commun., 1979) observed that in western American sections, the earliest $\mathrm{K}$ Zone corals always are fragmental. The reason for this has not yet been determined, but some sort of reworking is indicated. The highest CANINIA Zone fossils were found $326 \mathrm{~m}$ above the base of the Mercur limestone member. In the remaining $144 \mathrm{~m}$ of the Great Blue Limestone, fossils are sparse and not very diagnostic. The highest collection, $1 \mathrm{~m}$ below the top, was from a bryozoan bed which includes ARCHIMEDES.

Bryozoans appear to be abundant and diversified throughout the measured section. FENESTELLA sp., POLYPORA sp. and other fenestrates range throughout the section. Specimens of CYSTODICTYA appear to be more abundant in the Silveropolis limestone than in carbonate beds in the Long Trail Shale or Mercur limestone. TABULIPORA sp., FISTULIPORA sp., and STREBLOTRYPA sp., with related 
forms, appear to be common in the Great Blue Limestone measured section. The bryozoan faunule contains a number of new species. In general, the taxa of this faunule are similar to species that occur in the Upper Mississippian strata of Illinois and Kentucky (written commun., O. L. Karklins, 1979).

The top of the Great Blue Limestone Mercur limestone member is not the top of the Mississippian sediments. In Soldier Canyon, a few miles to the north, at least the lower $130 \mathrm{~m}$ of the Manning Canyon Shale is Late Mississippian.

\section{REGIONAL LITHOLOGIC and FAUNAL CORRELATIONS of the GREAT BLUE LIMESTONE}

It became increasingly apparent from geologic studies in the Oquirrh Mountains that regional correlation of Great Blue Limestoneage rocks in the eastern Great Basin is not simple owing to variations in the sedimentary rocks obtained in different parts of the Mississippian miogeocline and their transport individually eastward by thrust faults during the Late Cretaceous Sevier Orogeny. Sedimentary rock formation in the miogeocline is segmented by an east-trending, sometimes uplifted Uinta-trend basement lineament into an Oquirrh basin on the south side and the Sublette basin on the north side (Peterson, 1977). Nappes derived from both basins by Sevier thrust faults were juxtaposed across the Uinta-trend buttress in what is now the Oquirrh Mountains (Tooker, 1998). Rocks at the type locality of the Great Blue Limestone in the southern Oquirrh Mountains are different in some significant aspects from rocks of the same age in the northern Oquirrh Mountains, as well as those in the surrounding East Tintic, Wasatch, Stansbury, and Promontory Mountains. This is undoubtedly also true in other neighboring ranges. The decision to name correlative formational units in these ranges seems warranted, thus avoiding the past erroneous assumption that all rocks of this age are comparable because they were deposited in a simple homogeneous basin system. The close similarity of faunas in the sedimentary rock sequences provides a 
basis for making regional correlations. Thus, it is not a straightforward exercise to correlate the members of the Great Blue Limestone in the Silveropolis limestone (type section) with those of the lower members of the Great Blue Formation in the East Tintic Mountains (Morris and Lovering, 1961), even though they occur in the same nappe. There are similarities, but there also are distinct lithologic differences between the members (see Fig. 8). More detailed measurements of the Great Blue Limestone-type units elsewhere in the region will increase knowledge of the complex depositional environments that existed in the Paleozoic miogeocline.

FIGURE 8, NEAR HERE

East Tintic Mountains-Bingham Nappe

The East Tintic Mountains are located in the southernmost part of the Bingham nappe that was moved eastward by the Midas thrust (Morris, 1983) from its Oquirrh basin hinterland. The nappe contains numerous north-to-south transitions in Paleozoic sedimentary rock facies (Tooker, 1998) including those of the Great Blue Limestone. Morris and Lovering (1961) named and described four members of the Great Blue Formation in the East Tintic Mountains. These include the Topliff Limestone (91-141 $\mathrm{m}$ thick) at the base overlain by the Paymaster (190-m thick), the Chiulos (259-274 m-thick), and the Polker Knoll Limestone (183-213-m thick) members, which aggregate about $762 \mathrm{~m}$. The lower subunit of the Silveropolis limestone is readily correlated with the Topliff Limestone, both in thickness, fauna, and characteristic lithology. The Paymaster member in the East Tintic Mountains includes beds of sandstone, shale, and limestone that are probable age equivalents of the upper parts of the Silveropolis limestone, the Long Trail Shale, and perhaps the lower part of the Mercur limestone members in the Silveropolis Hill-Great Blue Limestone type section. There is no unit comparable with the Long Trail Shale in the Tintic area. 
The prominent CANINIA Zone of the Mercur limestone, missing in the East Tintic measured section, is probably represented temporally by the Chiulos shale and quartzite member. At Tintic, this interval is a thick black- to dark-brown, noncalcareous, fissile shale with intervening quartzite beds. No fossils have been found in the Chiulos shale except in its basal few centimeters. It apparently represents a starved-basin facies in the miogeocline that grades laterally northward into age-correlative limestone and shale containing abundant fossils.

The uppermost beds of the Great Blue Limestone, those above the top of the CANINIA Zone in the Silveropolis type section, seem to be largely equivalent to the Poker Knoll Member, as mapped by Morris and Lovering (1961) in the Seven-Mile Pass area.

Southern Oquirrh Mountains-Fivemile Pass Nappe

At the south end of the Oquirrh Mountains, rocks that are age correlative with the type Mercur limestone member occur in the Fivemile Pass nappe, which overlaps the Bingham nappe on the Clay thrust (Tooker, 1998). These rocks represent a transitional southwestern(?) Oquirrh basin facies. The rocks include brick clay deposits and thicker units of interbedded shale and limestone than those in the type Mercur limestone. These clay deposits may be time equivalents of the Chulios Member at Tintic. Variscite deposits also uniquely occur in the limestone here and in several ranges to the west, possibly on the same nappe (Sinkamkas, 1976).

Northern Oquirrh Mountains-Rogers Canyon Nappe

The stratigraphic succession of Mississippian Green Ravine to Permian Park City Formations in the Rogers Canyon nappe was detailed by Tooker and Roberts (1970). Their discovery of Mississippian fossils in rocks resembling those of the Pennsylvanian Oquirrh Group through a considerable thickness of rocks, near the mouth of the Green Ravine measured section, led to recognition of 
two distinct thrust-fault terranes or nappes in the Oquirrh Mountain. Tooker (1998) believed that sedimentary rocks in the Rogers Canyon nappe were deposited in the Sublette basin hinterland north of the Uinta trend. The nappe moved into its foreland position on the North Oquirrh thrust to overlap the Bingham and Pass Canyon nappes.

These rocks correlate faunally with "fairly early- to late Chester"-age rocks of the Mercur limestone member in the type Great Blue Limestone (Gordon and Duncan, 1970). They are also age correlatives, but not lithologic correlatives, of the Manning Canyon Shale and the lowest beds in the West Canyon Limestone of the Oquirrh Group (Tooker and Roberts, 1970). No Meramecian beds are present in the Green Ravine section, and rocks correlative with the type Silveropolis limestone member are not exposed there. The oldest exposed beds of the Green Ravine Formation resemble those of the Long Trail Shale and adjacent strata.

In spite of changes in lithology, rocks of this age can be recognized faunally. The CANINIA Zone or K Zone of Dutro and Sando (1963, p. 1974) is distributed widely in Upper Mississippian rocks in the western United States and is the basis for correlation with the Doughnut Formation in the northern part of the Wasatch Mountains and the upper part of the Chainman Shale in the Confusion Range and Granite Mountains in western Utah (Gordon and Duncan, 1970). Because of the structural and stratigraphic differences, Tooker and Roberts (1970) proposed the name Green Ravine Formation to emphasize the lithologic transitions in rocks of Great Blue Limestone age that are revealed there and in some of the neighboring ranges.

Wasatch Mountains-Timpanogos Nappe

Crittenden (1959) summarized the dual characteristics of Carboniferous rocks of the central and southern Wasatch Mountains, which include the thick and thin sequences of Baker and others (1949). The thick Timpanogos nappe stratigraphic sequence 
represents sediments deposited in the hinterland in a rapidly or continually subsiding Oquirrh basin. During the Sevier Orogeny, a nappe containing these rocks was emplaced by the Nebo-Charleston thrust, in what now is the Wasatch Mountains, in a topographic low in the craton on the south side of the uplifted Uinta trend. The Timpanogos nappe is overlain by the Midas thrust, which underlies the Bingham nappe in the Oquirrh Mountains (Tooker and Roberts, 1963). The lithologies and thicknesses of the Great Blue Limestone and other Early Paleozoic formations in the thick sequences of rocks in the Timpanogos and Bingham nappes are generally comparable (Tooker, 1999).

Wasatch Mountains-Mount Raymond Nappe

The thin allocthonous Mount Raymond nappe, which lies on the north side of the Uinta trend, was emplaced by the Mount Raymond thrust. The nappe represents contemporaneous shallow-shelf deposits from the eastern margin of the more slowly subsiding hinterland Sublette basin. These beds, for the most part, appear strikingly similar compositionally but are thinner lithologic units than those in the Timpanogos nappe. However, fossils in the Mount Raymond nappe, which are age-correlative with the Great Blue Limestone in the Timpanogos nappe, occur in the Doughnut Formation (Crittenden, 1959). The Doughnut is a 122-m thick black fossiliferous shale with scattered lenses of silty dark limestone and rusty-weathering quartzite at the base overlain by medium-bedded, black, fossiliferous limestone and dark chert in its type locality, which is on a tributary of Big Cottonwood Canyon. These rocks are thinner and more directly comparable with sedimentary rocks of Great Blue Limestone age in the Rogers Canyon nappe, which apparently were accumulated in deeper or more rapidly subsiding parts of the Sublette basin. The Doughnut Formation rests conformably on the Humbug Formation and is overlain, unconformably, by the Round Valley Limestone (Pennsylvanian). 
On the basis of its fauna, Dutro concluded that the Doughnut Formation "is probably equivalent to parts of the Great Blue Limestone and the Manning Canyon Shale" (Crittenden, 1959, p. 59). On the basis of structures and lithologies, Crittenden (1959) concluded that the name Great Blue Limestone is inappropriate for designating these thin-sequence rocks.

\section{Promontory Mountains}

Rocks in the Promontory Mountains on nappes, formed in the Sublette basin hinterland, was also emplaced by Sevier-age thrust faults. The rocks are different from those already noted in the Wasatch and Oquirrh Mountains and contain some perplexing data that need to be investigated more thoroughly. Following a brief field investigation of the upper Mississippian stratigraphy in the Promontory Mountains, Gordon (written commun., 1983) observed some correlation problems with rocks then being mapped as the Great Blue Limestone by M. D. Crittenden, Jr. The faunal collections were not from strata equivalent to any part of the type Great Blue Limestone in the Oquirrh Mountains. Gordon noted, "The collections from the Golden Spike Monument quadrangle are all from beds younger than the type Great Blue and are typical of those in the lower part of the Oquirrh Formation. Those from the Pokes Point quadrangle are from rocks older than the Great Blue and typical of the Uncle Joe Member of the Deseret Limestone in the type area of this formation at Ophir Canyon in the Oquirrh Mountains." This clearly indicates that the underlying sandstone mapped by Crittenden as Humbug Formation must be older than the type Humbug in Ophir Canyon, where the Humbug overlies the Deseret Limestone.

In conclusion, it seems clear that the stratigraphic section in the Promontory Range, mapped as the Great Blue Limestone, is not typical to that in the type region in the Oquirrh Mountains ( $M$. Gordon, Jr., written commun., 1983). The lower part of this massive limestone unit includes beds equivalent to at least the upper part of 
the Deseret Limestone and to the Humbug Formation of the Oquirrh Mountains. The missidentification of Great Blue Limestone-like outcrops in the Oquirrh Formation seems to be due to the inclusion of similar-looking lithologies. The Humbug Formation is a greater problem. In some places, the so-called Humbug is overlain by Meramecian limestones and seems to be older than the Humbug Formation in the type area. Thus, a new look at the lithologies of the several Promontory nappes is needed. Certainly, the extension of the Great Blue Limestone terminology in that range is questionable. The Sevier Orogeny has jumbled the record of complex sedimentation in the Paleozoic miogeocline.

Other Neighboring Ranges of the Oquirrh Mountains.

The Great Blue Limestone has been mapped in other nearby ranges west and south of the Oquirrh Mountains. Most of these geologic studies were made prior to the recognition of the impact of Sevier thrust faults within and between ranges (Tooker, 1983). Each of these ranges is composed of one or more nappes that have sampled strata deposited in different parts of the upper Mississippian basin. Complete stratigraphic and faunal records are not available for many of these nappes, and we are unable presently to do more than cite the existing pertinent literature and trust that additional research eventually will fill gaps in the record and permit a more rigorous correlation of upper Mississippian stratigraphy. The Moore and Sorensen (1979) map of the Tooele $1^{\circ}$ by $2^{\circ}$ quadrangle and study by Butkus (1975) provide the most recent interpretive compilation of significant information about individual ranges in the region based on the following studies of the following neighbor ranges: Northern Deep Creek Range (Nolan, 1935), Deep Creek Mountains (Bick, 1959), Stansbury Mountains (Rigby, 1958; and Tooker and Roberts, 1971), Silver Island Mountains (Schaeffer, 1960), Samaria Mountain, Idaho-Utah (Beus, 1968), Wellsville Mountain (Lindsay, 1977), Northern Lakeside and Grassy Mountains (Doelling, 1964), southern Lakeside Mountains (Young, 1955), Cedar Mountains (Maurer, 1970), northern Onaqui Mountains (Croft, 1956; 
and Moore and others, 1978), and Thorpe Hills and northern Tintic Mountains (Disbrow, 1957).

\section{REFERENCES CITED}

Armstrong, R. L., 1968, Sevier orogenic belt in Nevada and Utah: Geological Society of America Bulletin v. 79, p. 429-458.

Baker. A. A., Huddle, J. W., and Kinney, D. M., 1949, Paleozoic geology of north and west sides of Uinta Basin, Utah: American Association of Petroleum Geologists Bulletin, v. 33, no. 7, p. 1161-1187.

Beus, S. S., 1968, Paleozoic stratigraphy of Samaria Mountain, Idaho-Utah: American Association of Petroleum Geologists Bulletin, v. 52 , no 5 , p. $782-808$.

Bick, K.F., 1959, Stratigraphy of Deep Creek Mountains, Utah: American.Association of Petroleum Geologists Bulletin, v. 43, no. 5, p. 1064-1069.

Butkus, T. A., 1975, Sedimentology and depositional environments of the Great Blue Limestone (Late Mississippian), north central Utah: Utah University, Salt Lake City, Ph.D. thesis, 143 p.

Crittenden, M. D., Jr., 1959, Mississippian stratigraphy of the central Wasatch and western Uinta Mountains, Utah, in Williams, N. C., ed. Guidebook to the geology of the Wasatch and Uinta Mountains transition area: Intermountain Assoc. of Petroleum Geologists Guidebook, 19th Annual Field Congress, 1959, p. 63-74

Croft, M. G., 1956, Geology of the northern Onaqui Mountains, Tooele and Juab Counties, Utah: Brigham Young University Research Studies Geology Series, v. 3 , no. 1,44 p.

Disbrow, A. E., 1957, Preliminary geologic map of the Fivemile Pass quadrangle, Tooele and Utah Counties, Utah: U.S. Geological.Survey Mineral Investigation Field Studies Map MF-131, Scale 1:24,000.

Doelling, H. H., 1964, Geology of the northern Lakeside Mountains and the Grassy Mountains and vicinity: Utah University, Salt Lake City, Ph.D. thesis, $354 \mathrm{p}$.

Dutro, J. T, Jr., and Sando, W. J., 1963, New Mississippian formations and faunal zones in the Chesterfield Range, Portneuf quadrangle, southeast Idaho: American Association of. Petroleum Geologists Bulletin, v. 47, no. 11, p. 1963-1986.

Gilluly, James, 1932, Geology and ore deposits of the Stockton and Fairfield quadrangles, Utah: U.S. Geological Survey Professional Paper 173, 171 p.

Gordon, Mackenzie, Jr., and Duncan, H. M., 1970, Biostratigraphy and correlation of the Oquirrh Group and related rocks in the Oquirrh Mountains, Utah, in Tooker, E. W. and Roberts, R. J ., Upper Paleozoic rocks in the Oquirrh Mountains and Bingham Mining district, Utah: U.S Geological Survey Professional Paper 629-A, p. A38-A69.

Kornze, L. D., Faddies, T. B., Goodwin, J. C., and Bryant, M. A., 1985, Geology and geostatistics applied to grade control at the Mercur gold mine, Mercur, Utah: American. Institute of Mining and Metallurgical Engineers, Preprint 84-442, $212 \mathrm{p}$.

Lindsay, R. F., 1977, Petrology and petrography of the Great Blue Formation at Wellsville Mountain, Utah: Brigham Young University Geology Studies, v. 24, pt. 1, p. 115-136. 
Mamet, B. L., 1969, Foraminiferal zonation, in Sando, W. J., Mamet, B. L., and Dutro, J. T., Jr., Carboniferous megafaunal and microfaunal zonation in the Northern Cordillera of the United States: U.S. Geological Survey Professional Paper 613-E, p. E12-E17.

Maurer, R. E., 1970, Geology of the Cedar Mountains, Tooele County, Utah: Utah University, Salt Lake City, Ph.D. thesis, 184 p.

Moore, W. J. and Sorensen, M. L., 1979, Geology of the Tooele $1^{\circ}$ by $2^{\circ}$ quadrangle, Utah: U.S. Geological Survey Miscellaneous Investigations Series Map I-1132, Scale 1:250,000.

Moore, W. J., Sorensen, M. L., and Armin, R. A., 1978, Reconnaissance geologic map of Onaqui Mountains South quadrangle, Tooele County, Utah: U.S. Geological Survey Miscellaneous Field Studies Map MF-921, Scale 1:24,000.

Morris, H. T., 1983, Interrelations of thrust and transcurrent faults in the central Sevier orogenic belt near Leamington, Utah, in Miller, D. M., and others, eds. Tectonic and stratigraphic studies in the eastern Great Basin: Geological Society of America Memoir 157, p. 75-82.

Morris, H. T., and Lovering, T. S., 1961, Stratigraphy of the East Tintic Mountains, Utah: U.S. Geological Survey Professional Paper 361, 145 p.

Nolan, T. B., 1935, The Gold Hill mining district, Utah: U.S. Geological Survey Professional Paper 177, 172 p.

Peterson, J. A., 1977, Paleozoic shelf-margins and marginal basins, western Rocky Mountains-Great Basin, United States, in Twenty-ninth annual field conference guidebook-1977: Wyoming Geological Association, p. $135-153$.

Rigby, J. K., 1958, Geology of the Stansbury Mountains, eastern Tooele County, Utah, in Rigby, J. K., ed., Guidebook to the geology of Utah, No. 13, Geology of the Stansbury Mountains, Tooele County, Utah: Utah Geological Society, Salt Lake City, Utah, p. 1-134.

Roberts, R. J. and Crittenden, M. D., Jr., 1973, Orogenic mechanism, Sevier orogenic belt, Nevada and Utah, in Dejong, K. A. and Sholten, Robert, eds., Gravity and tectonics: John Wiley and Sons, New York, p. 409-428

Rose, P. R., 1976, Mississippian carbonate shelf margins, western United States: U.S. Geological Survey, Journal of Research, v. 4, no., 4, p. 449-466.

Schaeffer, F. E., 1960, Stratigraphy of the Silver Island Mountains, in Schaeffer, F. E. ed., Geology of the Silver Island Mountains, Box Elder and Tooele Counties, Utah and Elko County, Nevada: Guidebook to the geology of Utah, No. 13, Utah Geological Society, Salt Lake City Utah, p. 79-87.

Sinkamkas, John, 1976, Variscite, in Gemstones of North America, v. 1, D. Van Nostrand Co, Inc., Princeton, New Jersey, p. 231-232.

Spurr, J. E., 1895, Economic geology of the Mercur mining district, Utah: U.S. Geological Survey 16th Annual Report, pt. II, Papers of an economic character, p. 349-455.

Tooker, E. W., 1983, Variations in structural style and correlation of thrust plates in the Sevier foreland thrust belt, Great Salt Lake area, Utah, in Miller, D.M. and others, eds, Tectonic and stratigraphic studies in the eastern Great Basin: Geological Society of America, Memoir 157, p. 61-74.

1987, Preliminary geologic maps, cross sections, and explanation pamphlet for the Ophir and Mercur 7.5-minute quadrangles, Utah: U.S. Geological Survey Open-File Report 87-152, Scale 1:24,000. 1999. Geology of the Oquirrh Mountains, Utah: U.S. Geological Survey Open-File Report 99-571, 150 p. 
Tooker E. W. and Gordon, Mackenzie, Jr., 1978, Type section for the Great Blue Limestone, Oquirrh Mountains, Utah [abs]: Geological Society of America, Abstracts with Programs, v. 10., n. 5, p.240

Tooker, E. W., and Roberts, R. J., 1963, Comparison of Oquirrh Formation sections in the northern and central Oquirrh Mountains, Utah, in Geological Survey Research, 1962: U.S. Geological Survey Professional Paper 450-E, p. E22-E36.

1970, Upper Paleozoic rocks in the Oquirrh Mountains and Bingham mining district, Utah: U.S. Geological Survey Professional Paper 629-A, 76 p.

1971, Structures related to thrust faults in the Stansbury Mountains, Utah, in Geological Survey research 1971: U.S. Geological Survey Professional Paper 750-B, p. B1-B12. 1988, Preliminary geologic map, cross-sections, and explanation pamphlet for the Bingham Canyon Quadrangle, Salt Lake and Tooele Counties, Utah: U.S. Geological Survey Open-File Report 88-699, scale $1: 24,000$.

1992, Preliminary geologic map of the Stockton 7. 5-minute quadrangle, Tooele County, Utah: U.S. Geological Survey Open-File Report 92-385, scale $1: 24,000$.

1998, Geologic map of the Oquirrh Mountains and adjoining South and West Traverse Mountains, Tooele, Utah, and Salt Lake Counties, Utah: U.S. Geological Survey Open-File Map 98-581, scale 1:50,000.

Young, J. C., 1955, Geology of the southern Lakeside Mountains, Utah: Utah Geological and Mineralogical Survey Bulletin. v. 56, 116 p. 


\section{APPENDICES}

Measured stratigraphic sections of the Great Blue Limestone type and reference localities on the Bingham nappe in the Oquirrh Mountains, Utah

1-Measured stratigraphic section of the Silveropolis hill type locality. The lower part of the section is on the southwest slope of Hill 8790, facing the head of Long Trail Gulch, C, NE 1/4, sec. $25, T .5 S ., R .4 \mathrm{~W}$.; an upper offset portion of the section is from a point $0.6 \mathrm{~km}$ southeast along ridge rest to a point $0.1 \mathrm{~km}$ north of the road crossing the pass on the southeasttrending ridge at the head of Silverado Canyon, east toward the spring on the east-facing slopes of the South Fork, Ophir Canyon, in the SE 1/4, SE 1/4, NW 1/4, sec. 30, T. 5 S., R. 3 W., Mercur 7.5-minute quadrangle.

[Measured by Mackenzie Gordon, Jr., Helen Duncan, E. W. Tooker, and Raymond Lewandowski, September, 1962]

Thickness Distance

(m) above base

(m)

Manning Canyon Shale (lower bed only)

Mostly covered slope in floor of the South

Fork of Ophir Canyon. Shale, dark gray, weathers light tan-gray to purple-gray

and olive-gray, fine grained, interbedded

thin 5- to 7-cm-thick, platy, silty and

argillaceous limestone bands

Conformable contact

Mercur limestone member-upper member, Great Blue Limestone

38. Limestone, gray, weathers medium gray, some prominent nodular and lensing chert beds up to $3 \mathrm{~m}$ thick at $18 \mathrm{~m}$; fragmental fossil (bioclastic) debris abundant, sparse fossils 
USGS colln. 21195-PC from $1 \mathrm{~m}$ below top of unit

Fistuliporoid, gen. \& sp. indet., bifoliate form

Trepostomatous bryozoan, ramose form

Stenoporoid, ramose form

FENESTELLA sp. indet.

Fenestelloids, indet.

CYSTODICTYA? sp.

PSEUDOBATOSTOMELLA? sp.

STREBLOTRYPA? sp.

POLYPORA sp. indet.

ARCHIMEDES sp.

STREBLOTRYPA sp.

Rhomboporoid bryozoan, indet.

BUXTONIA sp.

PROTONIELLA? RICHARDSI Girty

OVATIA sp. indet. (fragments)

CLEIOTHYRIDINA sp. indet. (fragments)

COMPOSITA? sp. indet. (fragments)

Terebratuloid, gen \& sp. indet.

AVICULOPECTEN sp.

Pectenoid fragments, indet.

Crinoid columnals, indet.

37. Chert, gray, weathers light gray to light brownish-gray, subvitreous, very irregularly bedded with some lenticular layers of medium dark-gray, fine-grained to sandy limestone; no fossils, some organic debris; upper $7 \mathrm{~m}$ covered.

$10.0 \quad 450.5$

36. Covered, top is about $8 \mathrm{~m}$ above and east of the stream bed of South Fork, Ophir Canyon

$39.4 \quad 440.5$

35. Sandy limestone, gray, weathers medium gray, mottled locally, brownish weathered zones

in coarser sandy lenses, fine-grained massive ledges on dip slope

$0.8 \quad 400.3$

34. Argillaceous limestone and shale interbedded; float on covered slope

$5.9 \quad 394.4$

33. Limestone, medium dark gray, weathers gray, fine grained, silicified, irregularly rounded weathered surface, some calcite and quartz veinlets

$1.0 \quad 393.4$ 
32. Cherty limestone, massive, blocky, similar to unit 30

31. Covered, cherty limestone, limestone, and argillaceous limestone and shale float

30. Cherty limestone, medium light gray with brownish-gray cast, weathers lighter gray, tan-weathered chert in scattered pods, blocky, medium bedded; fossils poorly preserved in top $1 \mathrm{~m}$

29. Limestone, gray, weathers medium-light gray, silty to fine to sandy grained, platy to slabby beds; some beds fossiliferous; interlayered thin bands, dark-gray limestone, weathers gray, beds up to $20.3 \mathrm{~cm}$, hard siliceous, locally bioclastic with fossils

USGS colln. 21184-PC from $1.5 \mathrm{~m}$ above base of unit

FENESTELLA, sp. indet.

Fenestelloid, indet.

Trepostomatous bryozoan, indet.

EOLISSOCHONETES sp.

INFLATIA? sp.

28. Sandy limestone, gray, weathers tan to light gray, mottled, medium grained, thin bedded and platy, poorly exposed on covered slope

27. Limestone, gray, weathers tan to medium light gray or light brownish gray, silty to fine sandy, interbedded argillaceous limestone containing silicified productid brachiopods at $1.5 \mathrm{~m}$ and $2.1 \mathrm{~m}$; upper $3.2 \mathrm{~m}$ covered slope with shale and platy argillaceous limestone float

26. Cherty limestone, gray, weathers light gray, blocky, fine grained with lenticular layers of black chert, poorly exposed on ridge top; unfossiliferous. Thicker sandy limestone and cherty limestone up to $20 \mathrm{~cm}$ thick interbedded in upper $4 \mathrm{~m}$ 
Offset in measured section, $0.6 \mathrm{~km}$ northwest on ridge separating the head of Silverado Canyon and the South Fork, Ophir Canyon to the crest of Hill 8790. Measured section continues upslope to the west.

25. Shale and argillaceous limestone float; covered slope

24. Sandy limestone, dark gray, weathers gray, medium to coarse grained, beds up to $3 \mathrm{~m}$ thick, well jointed

23. Limestone, similar to unit 21 , but unfossiliferous

22. Limestone, similar to unit 21 ; basal $1 \mathrm{~m}$ thick brachiopod zone overlain by $2 \mathrm{~m}$ of sparse brachiopod fossils

USGS colln. 21180-PC from basal beds

CANINIA (SIPHONOPHYLLIA?) sp.

Stenoporoid bryozoan, foliate

FENESTELLA, 2 sp.

Rhomboporoid bryozoan, indet.

CYSTODICTYA? sp.

EOLISSOCHONETES sp.

INFLATIA BILOBATA Sadlick

FLEXARIA sp.

KROTOVIA? sp.

DIAPHRAGMUS sp.

ANTIQUATONIA aff. A. PERNODOSA Easton

?OVATIA sp. indet.

PALADIN CHESTERENSIS (Weller and Weller)

21. Limestone, dark gray, weathers medium dark gray, medium bedded, blocky float, partly silicified; interbedded silty to fine sandy limestone, weathers light brown; gray limestone contains silicified fossils

USGS colln. 21179-PC, 5 to $6 \mathrm{~m}$ above base of unit

FENESTELLA sp. indet.

Fenestelloid, indet.

ARCHIMEDES, sp. indet.

PSEUDOBATOSTOMELLA ? sp. 
EOLISSOCHONETES sp.

SPIRIFER BRAZERIANUS Girty

BEECHERIA sp. indet.

AVICULOPECTEN sp.

Gastropod, gen. \& sp. indet.

PALADIN CHESTERENSIS Weller and Weller

USGS colln. 27331-PC, same locality as above

Trepostomatous bryozoan, indet., ramose form

Stenoporoid, indet.,ramose form

FENESTELLA sp.

CYSTODICTYA? sp.

Rhomboporoid indet.

SEMICOSTELLA n. sp.

INFLATIA BILOBATA Sadlick

ANTIQUATONIA aff. A. PERNODOSA Easton

COMPOSITA? sp. indet.

SPIRIFER BRAZERIANUS Girty

Pelecypod, gen. \& sp. indet.

BORESTUS? sp.

High-spired gastropod, gen. \& sp. indet.

Crinoid columnals, indet.

USGS colln. 21182, same bed as 21179-PC but on ridge $0.6 \mathrm{kms}$ to southeast

Stenoporoid bryozoan, massive

Stenoporoid bryozoan, ramose

FENESTELLA sp.

Fenestelloid, indet (PENNIRETEPORA? sp.)

PENNIRETEPORA sp.

CYSTODICTYA sp. indet.

FISTULIPORA sp. indet.

Fistuliporoid, indet., bifoliate

STREBLOTRYPA ? sp.

TABULIPORA sp. (resembles T. aff. INERMIS)

INFLATIA BILOBATA Sadlick

FLEXARIA sp.

ANTIQUATONIA aff. A. PERNODOSA Easton

Crinoid columnals, indet.

USGS colln. 21183-PC, $4 \mathrm{~m}$ up section from 21182-PC

CANINIA (SIPHONOPHYLLIA?) sp.

20. Limestone, grayish black, weathers gray to

light brown, medium bedded, beds up to $0.3 \mathrm{~m}$

thick,fine grained, locally silty, well jointed; inter-

bedded 2-m thick, poorly jointed, platy dark

gray limestone intervals separate $0.3-\mathrm{m}$ thick

jointed limestone in lower part 
19. Limestone, dark gray to dark medium gray, weathers similarly, platy, thin bedded, very fine grained platy float; interbedded thin shale, particularly in the lower $3 \mathrm{~m}$, a few fossils.

The same section, $0.6 \mathrm{~km}$ southeast, exposes more massive limestone beds up to $23 \mathrm{~cm}$ thick below the the uppermost platy beds, contains sparse fossil fragments

USGS colln. 21181-PC, $1 \mathrm{~m}$ interval at middle of unit, offset approximately one-half mile southeast of 21161-PC

CANINIA (SIPHONOPHYLLIA?) cf. C. (S.?) NEVADENSIS (Meek)

FENESTELLA sp.

SEPTOPORA sp.

SEMICOSTELLA n. sp.

SANTIQUATONIA aff. A. PERNODOSA Easton

OVATIA sp.

Productoid, gen. \& sp. indet.

CLEIOTHYRIDINA sp.

SPIRIFER BRAZERIANUS Girty

ANTHRACOSPIRIFER sp. indet.

PALADIN sp. indet.

18. Limestone, gray, weathers lighter gray, fine grained, silty, few chert nodules; fossiliferous, at $46 \mathrm{~m}$ CANINIA coral bed at the top

USGS colln. 21161-PC from $4 \mathrm{~m}$ above base

CANINIA (SIPHONOPHYLLIA?) cf. C. (S.?) EXCENTRICA (Meek)

RUGOSOCHONETES sp.

N. gen. aff. ELLIOTELLA, n. sp. ANTIQUATONIA aff. A. PERNODOSA Easton COMPOSITA SUBQUADRATA TRANSVERSA Girty? ANTHRACOSPIRIFER SP.

USGS colln. 27333-PC, from the same horizon in the offset section to the southeast

CANINIA (SIPHONOPHYLLIA?) cf.. C. (S.?)

NEVADENSIS (Meek)

Stenoporoid bryozoan (?), foliate, incrusting

POLYPORA sp.

SEPTOPORA sp. indet.

INFLATIA sp.

ANTIQUATONIA aff. A. PERNODOSA Easton

SPIRIFER BRAZERIANUS Girty

PALADIN CHESTERENSIS (Weller and Weller) 
17. Limestone, dark gray, weathers gray, finegrained; banded, ellipsoidal black chert nodules, weathers light brownish gray

$6.0 \quad 278.2$

16. Bedded chert or very siliceous quartzite, dark gray, weathers gray, very fine grained, brittle, highly jointed in beds $13-30 \mathrm{~cm}$ thick

$10.9 \quad 267.3$

15. Limestone, dark gray, weathers light brownish to light olive-gray, impure silty, platy in beds up to $0.4 \mathrm{~m}$ thick, local layers are well banded in upper part, grades upward into sparsely fossiliferous pure limestone. A bed about $1.0 \mathrm{~m}$ thick has FLEXARIA sp. at $36 \mathrm{~m}$

$59.3 \quad 208.0$

14. Covered interval, platy limestone float, small fragments

$8.8 \quad 199.2$

13. Limestone, dark gray, weathers gray with reddish tinge, fine grained, less siliceous than unit 9, slightly fossiliferous, poor precrustation

USGS colln. $21160-\mathrm{PC}$ is $11 \mathrm{~m}$ above base Productoid, gen. \& sp. indet. AVICULOPECTEN sp.

12. Covered interval, limestone float similar to unit 9

11. Limestone, dark gray, weathers gray, very fine grained, similar to unit 9

$0.5 \quad 160.4$

10. Covered interval, limestone float similar to unit 9

9. Limestone, dark gray, weathers gray, very fine grained with sandy limestone and black chert clots and bands, and spheroidal to lenticular siliceous inclusions that weather brownish, beds $15 \mathrm{~cm}$ to $0.6 \mathrm{~m}$ thick, visible fossils occur as scattered clastic fragments, top bed contains more detrital material and several brachiopod 
and coral cross sections

$12.2 \quad 130.8$

USGS colln. 27329-PC at $2 \mathrm{~m}$ above base;

RUGOSOCHONETES sp.

Productoid, gen. \& sp. indet.

SPIRIFER BRAZERIANUS Girty

SULCATOPINNA sp.

8. Covered slope, platy limestone, dark gray, weathers gray, banded, more siliceous bands weather dark brownish gray, more limy materials weather light brownish gray, coral from top of unit is CANINIA (SIPHONOPHYLLIA?) sp. indet.

Tertiary porphyry sill, altered

7. Covered slope, platy limestone and porphyry float; limestone, dark gray, weathers gray, very fine grained

$16.0 \quad 50.2$

Tertiary porphyry dike crosses at small angle to bedding

Unit 7 continues

6. Limestone, gray, weathers gray, medium to coarse grained in beds up to $0.3 \mathrm{~m}$ thick separated by thin shale and limestone partings and layers, poorly preserved fossil poor exposures

5. Sandstone, similar to unit 3

$6.4 \quad 33.4$

4. Covered interval, mostly platy float from interbedded layers 0.3 to $1 \mathrm{~m}$ thick composed of argillaceous shale, calcareous sandstone with thin limestone interlayers, siltstone, fossiliferous limestone, and interbedded shale, argillaceous limestone, and coarse arenaceous crinoidal limestone; float from thin porphyry sill (?) of unknown thickness the in lower $5 \mathrm{~m}$; unit similar to unit 4 of Long Trail Shale; shale grayish black, weathers mottled brownish gray; 
limestone, gray, weathers gray, platy, fine grained, locally with fossil zones

USGS colln. 27328-PC from crinoidal limestone 1.2-1.8 $\mathrm{m}$ above base of unit may contain forams, but also includes poorly preserved fossils identified in the field as FENESTELLA, INFLATIA, FLEXARIA, large productoid fragments, indet., CLEIOTHYRIDINA, SPIRIFER BRAZERIANUS Girty, ANTHRACOSPIRIFER, SEPTIMYALINA, and LIMIPECTEN

Porphyry sill

3. Sandstone, light brownish gray, weathers brown, medium grained, subangular to subrounded grains in siliceous matrix

2. Covered slope, float from limestone and siltstone dark gray, thin bedded, resembles unit 1 of the Long Trail Shale

1. Limestone and shale, interbedded; limestone, dark gray, weathers gray to mottled brown, medium to coarse grained, in three prominent limestone outcrop ribs up to $15 \mathrm{~cm}$ thick separated by shale. Interlayers of shale and limestone similar and limestone resembles unit 4 of Long Trail Shale; very fossiliferous

USGS colln. 20267-PC

Conulariid, gen. \& sp. indet.

Trepostomatous bryozoans, 2 forms, ramose

Stenoporoid, two forms, incrusting and massive

FENESTELLA sp. (two forms)

CYSTODICTYA? sp.

Bryozoan indet.

RHIPIDOMELLA sp. (small)

SCHIZOPHHORIA aff. S. TEXANA Girty

SCHIZOPHORIA cf. S. RESUPINOIDES (Cox)

ORTHOTETES sp.

EOLISSOCHONETES sp.

RUGOSOCHONETES ? sp. indet.

BUXTONIA ? sp. indet.

ANTIQUATONIA n. sp. A

OVATIA sp. indet.

COMPOSITA SUBQUADRATA (Hall)

CLEIOTHYRIDINA Sp.

SPIRIFER BRAZERIANUS Girty

ANTHRACOSPIRIFER CURVILATERALIS BRUTUS Gordon 
BRACHYTHYRIS sp.

MARTINIA sp. indet.

PUNCTOSPIRIFER TRANSVERSUS (McChesney)?

?RETICULARIINA GONIONOTA (Meek)

HUSTEDIA sp.

BEECHERIA sp.

GIRTYELLA? sp.

AVICULOPECTEN sp.

LIMIPECTEN? sp.

STREBLOPTERIA? sp.

CYPRICARDELLA cf. C. BRAZERIANA Girty

CYPRICARDELLA cf. C. VARICOSA Girty

SPHENOTUS sp. (two forms)

EDMONDIA? sp.

WORTHENIA sp.

Coiled nautiloid, gen. \& sp. indet.

PALADIN sp.

Crinoid columnals, indet.

USGS colln. 21159-PC from same unit, near locality 20267-PC at base of unit

AMPLEXIZAPHRENTIS sp.

SCHIZOPHORIA cf. S. RESUPINOIDES (Cox)

RUGOSOCHONETES sp. indet.

Productoid, n. gen., n. sp. aff. PRODUCTUS

MOOREFIELDIANUS Girty

INFLATIA sp. indet.

ANTIQUATONIA n. sp. A

OVATIA aff. O. DUODENARIA (Easton)

Rhynchonelloid, gen. \& sp. indet.

COMPOSITA SUBQUADRATA (Hall)?

SPIRIFER BRAZERIANUS Girty

ANTHRACOSPIRIFER CURVILATERALIS BRUTUS Gordon?

BRACHYTHYRIS sp.

TORYNIFER SETIGER (Hall)?

PARALLELODON sp.

SEPTIMYALINA sp. indet.

LEPTODESMA sp.

NATICOPSIS aff. N. GENEVIEVENSIS Meek and Worthen

Total thickness of the Mercur limestone member measured

Conformable contact (?)

Long Trail Shale Member, Great Blue Limestone

4. Shale and limestone, interbedded; shale is dark gray, weathers gray, slightly more calcareous than in similar units below, platy, poorly exposed; limestone is dark gray, weathers 
brownish gray, fine- to medium-grained with crinoidal layers, thin bedded up to $10 \mathrm{~cm}$ thick, grades upward into banded shaly siliceous siltstone; fossiliferous

USGS colln. 20266-PC, from basal part of unit

AMPLEXIZAPHRENTIS sp.

FENESTELLA sp.

TABULIPORA sp. (resembles T. INERMIS (Girty))

LINGULA sp.

SCHIZOPHORIA aff. S. TEXANA Girty?

SCHUCHERTELLA sp.

RUGOSOCHONETES sp.

EOLISSOCCHONETES sp.

PROTONIELLA RICHARDSI (Girty)

INFLATIA sp. indet.

KROTOVIA? sp. indet.

OVATIA aff. O. DUODENARIA (Easton)

N. GEN. aff. PUGNOIDES n. sp.

COMPOSITA SUBQUADRATA (Hall)

COMPOSITA sp.

CRURITHYRIS sp.

ANTHRACOSPIRIFER CURVILATERALIS BRUTUS Gordon

EUMETRIA? sp. indet.

HUSTEDIA sp.

VOLSELLINA? sp.

CYPRICARDELLA cf. C. BRAZERIANA Girty

USGS colln. 21158-PC, same locality

Horn coral, gen. \& sp. indet.

FENESTELLA sp.

RHIPIDOMELLA aff. R. NEVADENSIS (Meek)

SCHIZOPHORIA aff. S. TEXANA Girty?

SCHIZOPHORIA cf. S. RESUPINOIDES (Cox)

ORTHOTETES sp.

RUGOSOCHONETES $\mathrm{sp}$.

EOLISSOCHONETES sp. indet.

INFLATIA? sp. indet.

KROTOVIA sp.

ECHINOCONCHUS sp. indet.

ANTIQUATONIA? sp.

OVATIA sp. indet.

OVATIA aff. O. DUODENARIA (Easton)

COMPOSITA SUBQUADRATA (Hall)

SPIRIFER BRAZERIANUS Girty

ANTHRACOSPIRIFER CURVILATERALIS BRUTUS Gordon

BRACHYTHYRIS sp.

TORYNIFER SETIGER (Hall)?

MARTINIA sp. indet.

PUNCTOSPIRIFER TRANSVERSUS (McChesney)

AVICULOPECTEN sp. 
Nautiloid, gen. \& sp. indet.

3. Shale, grayish black to very dark gray, weathers mottled brownish-gray, fissile with sparse silty particles, mostly clay shale, poorly exposed

Porphyry sill

2. Limestone and shale, interbedded; limestone is silty and siliceous, brownish gray, weathers medium brown with greenish cast, very fine grained, locally fossiliferous brachiopod, bryozoan,and crinoid fragments; shale dark gray, weathers gray, fine grained, thin bedded, fissile; mostly covered slope

1. Limestone, silty and siliceous, brownish gray, weathers medium brown with greenish cast, very fine grained, sparse fossils, grades upward in upper third of unit into banded shaly

Total thickness of the Long Trail Shale

Conformable contact

Silveropolis limestone member-lower member, Great Blue Limestone

39. Arenaceous limestone, brownish gray, weathers brown, medium grained, medium bedded (averages $0.5 \mathrm{~m}$ thick), siliceous, breaks with conchoidal fracture, sparsely fossiliferous

USGS colln. 27317-PC at top of unit

LINGULA sp.

Orthotetoid, gen. \& sp. indet.

N. gen. aff. PUGNOIDES, n. sp.

USGS colln. 20265-PC at same locality

AMPLEXIZAPHRENTIS sp.

Orthotetoid gen. \& sp. indet.

INFLATIA sp.

OVATIA sp. indet.

N. gen. aff. PUGNOIDES, n. sp.

COMPOSITA SUBQUADRATA (Hall)

and varieties 
ANTHRACOSPIRIFER cf. A. SHAWI Gordon

USGS colln. 27318-PC at base of unit

Horn coral, indet.

AMPLEXIZAPHRENTIS sp.

Stenoporoid, incrusting form

RUGOSOCHONETES sp.

INFLATIA cf. I. BILOBATA Sadlick

OVATIA sp. indet.

ECHINOCONCHUS sp. indet.

ANTIQUATONIA sp. indet.

CLEIOTHYRIDINA sp. indet.

Pelmatozoan debris, indet.

38. Shale, siltstone, limestone, and calcareous

sandstone interbedded; shale, thin bedded, very dark gray, very fine grained, weathers

light yellowish gray separates more resistant limestone and sandstone ribs; limestone, dark gray, weathers grayish yellow-green; siltstone brownish gray, weathers brown, fine to medium grained, breaks with conchoidal fracture, not fossiliferous

37. Limestone, medium dark gray, weathers dark gray, medium bedded $(0.5 \mathrm{~m})$, siliceous, breaks with a conchoidal fracture, unfossiliferous

$0.9 \quad 253.4$

36. Shale with interbedded siltstone, fine sandstone; shale very dark gray, weathers light yellowish brown, very fine grained; sandstone is yellowish $\tan$ with stringers of dark gray, somewhat fossiliferous limestone that weathers grayish yellow-green

$6.1 \quad 247.3$

35. Argillaceous limestone, medium light gray, weathers light brown, interlayered fine-grained silty limestone, light gray, weathers moderate yellowish brown, and bioclastic and fossiliferous limestone in lower $6 \mathrm{~m}$, are gray to medium dark gray, weathers, light gray, and brown; contains crinoids, bryozoans and brachiopods 
Horn coral

AMPLEXIZAPHRENTIS sp.

FENESTELLA sp.

Fenestelloids, indet.

TABULIPORA sp. (resembles TABULIPORA AMERICANA

Ulrich, from Illinois and Kentucky)

Trepostomes, indet., bifoliate forms

Stenoporoid, indet. incrusting form

OVATIA sp. indet.

COMPOSITA sp.

ANTHRACOSPIRIFER $\mathrm{cf}$. A. SHAWI EXOLETUS

Gordon

Pelmatozoan debris, indet.

34. Limestone, medium dark gray, weathers gray,

thin to medium bedded, local fragmental fossil

(bioclastic) sand layers

$3.7 \quad 234.6$

33. Argillaceous limestone, buff, weathers, light brown, platy to thin bedded, locally with nodular black chert, thin siliceous limestone interlayers

32. Limestone, medium dark gray, weathers gray, thin to medium bedded, local fossil fragment (bioclastic) sand layers

$5.7 \quad 225.4$

31. Limestone, very dark gray, weathers bluish gray, very fine grained, locally interlayered nodular black chert and argillaceous limestone; sparsely fossiliferous

$5.7 \quad 219.7$

30. Limestone, medium dark gray, weathers gray, slightly sandy; $30 \mathrm{~cm}$ massive ledge-forming bed at base contains silicified ORTHOTETES on uppermost surface

USGS colln. 27326-PC

ORTHOTETES, cf. O. KASKASKIENSIS (McChesney)

INFLATIA sp.

29. Nodular limestone and calcareous shale, interbedded; limestone medium dark gray, weathers gray to light brown; shale mostly covered 
28. Limestone, gray, weathers medium light gray, fine grained, thin to medium bedded, up to $25 \mathrm{~cm}$ thick; local fragmental fossil (bioclastic) same at top

27. Shale float, covered slope

26. Limestone, gray, weathers gray, medium grained thin bedded slabs up to $8 \mathrm{~cm}$ thick; fragmental fossil (bioclastic) lenses locally

25. Shale float on covered slope $2.6 \quad 190.5$

24. Cherty limestone, gray, weathers gray, thin bedded, large irregular pods and nodules of grayish tan chert, fine lacing of calcite veinlets; no fossils

23. Shale and thin platy limestone float, covered

22. Arenaceous limestone, gray, weathers gray, medium bedded, up to $23 \mathrm{~cm}$ thick,; fossil $\begin{array}{llll}\text { fragments and crinoids in fossiliferous limestone } & 9.5 & 176.2\end{array}$

USGS colln. 21194-PC at base of unit CYSTODICTYA aff. C. MASOR Ulirch FISTULIPORA sp.

Fistuliporoid, foliate to massive form FENESTELLA sp.

Fenestelloid? indet. PENNIRETEPORA sp.

TABULIPORA aff. T. INERMIS (Girty)

Stenoporoid, ramose form

Stenoporoid, foliate form

RUGOSOCHONETES? sp.

ANTIQUATONIA sp. A

CRANAENA? sp.

USGS colln, 27320-PC at $0.6 \mathrm{~m}$ above base of formation

Horn coral, indet.

AMPLEXIZAPHRENTIS sp.

CYSTODICTYA aff. C. MASOR Ulrich

Stenoporoid, incrusting form

FENESTELLA sp.

FISTULIPORA sp. 
PENNIRETEPORA $\mathrm{sp}$

ECHINOCONCHUS sp. (small)

ANTIQUATONIA sp. A

CLEIOTHYRIDINA sp.

ANTHRACOSPIRIFER cf. A. SHAWI Gordon

Fish remains, indet.

21. Limestone, dark gray, weathers medium dark gray fine grained, black chert layers, lenses and nodules up to $10 \mathrm{~cm}$ thick

$1.5 \quad 174.7$.

20. Calcareous shale and argillaceous limestone, interbedded; shale, light gray, weathers buff, argillaceous limestone locally contains nodular chert; mostly covered

19. Limestone, gray to dark gray, weathers gray with bluish cast, thin bedded up to $15 \mathrm{~cm}$, slabby; interlayered tan, fine grained

calcareous sandstone; abundant silicified fossils

$2.8 \quad 169.7$

USGS colln. 21193-PC

Fistuliporoid, incrusting form

CYSTODICTYA aff. C. MAJOR Ulrich

FENESTELLA sp. (two species)

POLYPORA sp.

STREBLOTRYPA sp.

TABULIPORA? sp., encrusting

Stenoporoid, incrusting form

Rhomboporoids indet. (three species)

Productoid, indet. (small, semireticulate)

Gastropod, platyceratacean form

FENESTELLA sp.

USGS colln. 27321-PC

Fenestelloid, indet.

POLYPORA sp.

CYSTODICTYA aff. C. MAJOR Ulrich

FISTULIPORA sp.

STREBLOTRYPA sp.

TABULIPORA? sp.

Crinoid columnals, indet.

Pelmatozoan debris, indet.

18. Limestone, medium dark gray, weathers gray, fine grained, thin bedded, jointed; poorly exposed block float, mostly covered 
17. Cherty limestone and black block chert, interbedded; limestone is gray, weathers gray,

fine grained, thin bedded up to $10 \mathrm{~cm}$, jointed, chert mostly in lower $1.8 \mathrm{~m}$

$4.1 \quad 159.6$

16.. Black chert and gray limestone; float-covered slope

15. Limestone, medium dark gray, weathers gray, fine to medium grained, thin to medium bedded; interlayered fragmental fossil (bioclastic) sand lenses; very fossiliferous; upper $.5 \mathrm{~m}$ covered

USGS colln. 21192-PC

FENESTELLA sp.

POLYPORA sp.

CYSTODICTYA sp.

TOMIPRODUCTUS sp.

STRIATIFERA cf. S. BRAZERIANUS (GIRTY)

USGS colln. 27325-PC
Horn coral, indet.

AMPLEXIZAPHRENTIS sp.

CYSTODICTYA aff. C.. MAJOR Ulrich

FISTULIPORA sp.

FENESTELLA sp.

STREBLOTRYPA sp.

TABULIPORA? sp. ,encrusting

Orthotetoid?, gen \& sp. indet.

TOMIPRODUCTUS sp.

STRIATIFERA cf. S. BRAZERIANA (Girty)

GIRTYELLA sp.

PALADIN sp.

14. Shale(?), covered slope $\quad 1.9 \quad 142.6$

13. Quartzitic sandstone, tan, fine grained, thin bedded; interlayered calcareous sandstone, mostly covered slope

$9.2 \quad 133.4$

12. Shale and platy limestone float on covered slope

$2.9 \quad 130.5$

11. Calcareous sandstone, olive gray, weathers 
brown-gray, medium grained, thin bedded; interlayered limestone, gray, fine grained, thin bedded, mostly float-covered slope

$2.2 \quad 128.3$

10. Argillaceous limestone, dark gray, platy to thin bedded, mostly float-covered slope

9. Calcareous sandstone, tan, weathers buff, fine to medium grained, platy to thin bedded, thick weathered surface rind, had silicified interior; hard siliceous calcareous bed at top; upper part mostly covered slope

8. Limestone, light tan-gray, weathers slightly lighter $\tan$, fine to medium grained, thin bedded, locally silicified, abundant calcite veinlets and blebs; not fossiliferous; mostly covered in upper $0.8 \mathrm{~m}$

7. Platy limestone and shale float, mostly covered $26.4 \quad 93.3$

6 Limestone, dark gray, weathers light blue-gray, fine grained, thick to medium bedded; interlayered argillaceous limestone, poorly exposed

5. Argillaceous limestone, dark gray, thin bedded; mostly covered, locally fossiliferous, silicified

USGS colln. 21191-PC, between 2 and $5 \mathrm{~m}$ TOMIPRODUCTUS sp.

OVATIA sp.

COMPOSITA aff. C. PENTAGONA Weller

TYLOTHYRIS sp.

BRACHYTHYRIS sp.

Echinoid spines, indet.

USGS colln. 27324-PC, at $3.8 \mathrm{~m}$ above base TOMIPRODUCTUS sp.

OVATIA sp.

COMPOSITA aff. C. PENTAGONA Weller

TYLOTHYRIS sp.

BRACHYTHYRIS sp.

EUMETRIA VERNEUILIANA (Hall)

GIRTYELLA

4. Limestone, dark gray, weathers gray, fine 
grained, thin to medium bedded; interlayered

platy silty limestone; fossiliferous

USGS colln. .21887-PC from $0.3 \mathrm{~m}$ thick bed at $3 \mathrm{~m}$ above base

FABEROPHYLLUM sp.

USGS colln. 21189-PC at $6 \mathrm{~m}$ above base

PLEUROSIPHONELLA VIRGINICA (Butts)

USGS colln. 27323-PC at $6 \mathrm{~m}$

PLEUROSIPHONELLA sp.

FABEROPHYLLUM sp.

CLISIOPHYLLUM sp.

CANADIPHYLLUM? sp.

Zaphrentoid coral, indet.

Horn corals, indet.

USGS colln. 21190 at $21 \mathrm{~m}$ above base

COMPOSITA? sp. indet.

TYLOTHYRIS sp.

PROMYTILUS sp.

MYALINA? sp. indet.

AVICULOPECTEN sp.

SCHIZODUS sp.

USGS colln. 612F35a at $30 \mathrm{~m}$ above base

Silicified brachiopods and "worm markings," indet.

3. Limestone, dark gray, weathers gray, fine grained, thin to medium bedded, locally silicified, conchoidal fractured; interlayered arenaceous, bioclastic and argillaceous limestone; locally very fossiliferous

USGS colln. 21185-PC at $0.3 \mathrm{~m}$ above base

PLEUROSIPHONELLA? sp.

FABEROPHYLLUM? sp.

CLISIOPHYLLUM sp.

Horn corals indet.

CRURITHYRIS? sp.

Bellerophontacean, gen. \& sp. indet.

USGS colln. 21186-PC in $0.3 \mathrm{~m}$-thick limestone at $11 \mathrm{~m}$ above base

PLEUROSIPHONELLA cf. P. VIRGINICA (Butts)

FABEROPHYLLUM sp.

ROTIPHYLLUM sp.

CLISIOPHYLLUM sp.

Horn corals, indet. 
USGS colln $21187-\mathrm{PC}$ in $0.5 \mathrm{~m}$ limestone at $17 \mathrm{~m}$ above base

FABEROPHYLLUM sp.

2. Limestone, dark gray, weathers light gray to gray, very fine grained, thin to medium bedded, well jointed, brittle, platy and blocky float

1. Mostly argillaceous limestone and shale float, limestone dark gray, fine grained, thin bedded, platy.

Total thickness of Silveropolis Limestone measured

Total thickness of the Great Blue Limestone

Conformable contact

Humbug Formation (upper bed only)

Quartzitic sandstone, grayish tan, weathers dark brown, fine sand, slightly banded, thin to medium bedded, locally platy. 
2-Measured stratigraphic section of the reference section of the Mercur Member, upper limestone about 1.0-1.75 km northeast of the Mercur mining district, Utah. The section trends northeastward across the north end of hill (elev. 7,712 ft) south of Meadow Canyon, beginning at about t) $6,800 \mathrm{ft}$. contour in the SW 1/4, NW 1/4, sec. 5, T. $6 S ., R .3 \mathrm{~W}$., eastward across the crest, north of the summit, to the low divide in the Mercur 7 1/2-minute quadrangle, Utah.

[Measured by Mackenzie Gordon, Jr., and Edwin W. Tooker, August 1980. Fossil collections identified by J. Thomas Dutro, Jr, January 1997]

Thickness Distancı

(meters) above ba:

(meters)

Manning Canyon Shale, covered zone in shale

Conformable contact

Mercur Limestone Member, Great Blue Limestone (481.8 m-thick)

47. Argillaceous and fossiliferous, sandy, and cherty limestones, interbedded; limestones medium gray, weather medium bluish gray, fine grained, thin to medium bedded with occasional irregular fragmental (bioclastic) fossil sand and chert nodule layers, fossiliferous; bold outcrops and blocky float

USGS collns. 27980-PC, 27982-PC, and 27986-PC from this bed where measured on hill on north side of Meadow Canyon

USGS colln. 27980-PC

ARCHIMEDES sp. (bryozoan)

Amplexizaphrentoid coral, indet.

Echinoderm debris, indet.

BUXTONIA sp.

CLEIOTHYRIDINA sp.

MYALINA sp.

Mollusks, indet. 
USGS colln. 27982-PC

ARCHIMEDES sp.

Ecinoderm debris, indet.

USGS colln. 279886-PC

ARCHIMEDES sp.

46. Silty and argillaceous limestone, interbedded;

medium gray, weather medium light gray,

fine grained, thin bedded with fine to coarse

banding; platy, rounded float fragments

$2.8 \quad 455.7$

45. Sandy and argillaceous limestones, interbedded;

medium dark gray, weather light tannish-gray,

thin bedded; platy float-covered slope

$13.4 \quad 452.9$

44. Silty and argillaceous limestones, interbedded; silty limestone is medium light gray, weathers medium light gray with brownish tint; argillaceous limestone is medium dark gray, weathers light gray and medium light gray; both are fine grained, thin bedded; section becomes more argillaceous in upper part; platy float on mostly covered slope

43. Shale; soil-covered shale interval

42. Sandy and argillaceous limestone, interbedded; dark gray, weathers medium dark gray, fine grained to sandy, local bioclastic lenses and lenses of black chert; locally fossiliferous

USGS colln. 27996-PC at $6.9 \mathrm{~m}$ above base Chonetid brachiopods, indet. OVATIA sp.

41. Argillaceous limestone and silty limestone, interbedded; medium dark gray, weathers bluish gray, fine grained, thin bedded, including irregularly spaced platy beige siltstone layers; fossiliferous

USGS colln. 27995-PC at $31 \mathrm{~m}$ (top of ridge) OVATIA sp. 
40. Argillaceous limestone and silty limestone, interbedded; dark gray, weather bluish gray, fine grained, thin bedded; grayish black chert nodules occur in local pods in brownish-grayweathering silty limestone; platy to blocky float

$18.5 \quad 375.4$

39. Silty and argillaceous limestones, interbedded with thin cherty limestone layers; limestone is dark grayish-black, weathers medium gray, fine grained; platy and blocky float among scattered outcrops

38. Sandy limestone with interbedded argillaceous and cherty limestone layers; dark grayishblack, weathers medium gray, fine grained, thin to medium bedded, locally banded with brownish gray-weathering, coarse sandy layers containing gray chert nodules; platy float,

$34.1 \quad 340.9$

37. Shale and sandy limestones, interbedded; fissile shale mostly covered; limestone is medium gray, weathers light gray, thin to medium bedded; platy and blocky float

36. Shale, light gray, weathers same, fine grained fissile; covered slope

35. Argillaceous limestone, medium dark gray, weathers slightly lighter gray, medium grained, local thin bioclastic debris layers, bellerophontid fossils; sparse blocky float

34. Fossiliferous and argillaceous limestone, interbedded; fossil limestone medium gray to dark gray, weathers dark gray, fine to coarse grained, platy, contains some bioclastic layers, very fossiliferous with brachiopods, snails, and bryozoans. Argillaceous limestone dark gray, weathers medium gray, fine grained, medium bedded up to $0.3 \mathrm{~m}$; also locally fossiliferous (snails) and bioclastic interbedded layers, blocky float 
USGS colln. 27994-PC (mostly float specimens)

Bryozoans, indet. (massive)

INFLATIA sp.

Spiriferid brachiopods, indet.

Bellerophonts, indet.

33. Sandy limestone, dark gray, weathers gray, fine

to medium grained calcarenite, thin to

medium bedded; mostly covered slope

$6.7 \quad 279.3$

32. Argillaceous and silty limestone, interbedded;

medium gray, weathers medium blue-gray with

tan bands, fine to medium grained, thin bedded;

platy float

$3.7 \quad 272.6$

31. Sandy limestone, black, weathers dark gray, medium-grained calcarenite sand with fossil fragments; partly covered

$4.5 \quad 268.9$

30. Argillaceous limestone and silty limestone, interbedded; grayish black, weather gray and brownish, fine to medium grained, irregular banding produced by silty laminae

$8.6 \quad 264.4$

29. Calcareous siltstone, silty limestone, and shale, interbedded; shale gray, weathers light gray; silty limestone medium dark gray, weathers brownish tan; calcareous siltstone medium gray, weathers tannish gray; fine grained laminae, thin bedded, banded; platy float, mostly covered

28. Shale; covered slope

27. Calcareous siltstone, silty limestone, and shale, interbedded; siltstone medium gray, weathers tannish gray, fine grained, thin bedded and laminar, banded; limestone gray, weathers brownish tan, fine grained, thin bedded; shale gray, weathers light gray, thin laminae between thicker limestone and siltstone; mostly covered slope with platy float 
26. Shale, dark gray, weathers light gray, fine grained;

platy float, covered slope

25. Sandy limestone, medium gray, weathers light gray with reddish-gray tinge, thin bedded containing irregular mud lenses at base; graded upward into thin to medium bedded with more common mud balls and lenses; upper part banded sandy and fine sandy limestone with dark gray mud lumps; top massive limestone bed is $0.3 \mathrm{~m}$ to $1.5 \mathrm{~m}$ thick carrying sparse fossils and bioclastic sandy lenses

24. Shale; covered slope

$8.7 \quad 221.3$

23. Cherty limestone, dark gray to black, weathers dark gray, medium to fine grained, medium bedded, contains sparse irregular gray chert nodules; sparsely fossiliferous, bioclastic lenses, brachiopod, coral, trilobite

float

22. Shale and argillaceous limestone, interbedded; mostly covered slope, platy limestone float

21. Limestone, medium gray to black, weathers dark gray, medium to thick bedded, prominent ledgeformer, fractured and healed with white calcite; blocky float

$3.0 \quad 205.8$

USGS colln. 27993-PC in uppermost $0.3 \mathrm{~m}$ contains most abundant fossils.

Small horn corals, indet.

CANINIA? sp.

SPIRIFER BRAZERIANUS

INFLATIA cf. I BILOBATA

20. Silty and argillaceous limestone, interbedded; dark gray to black, weathers light gray, siliceous bands tan-gray, fine grained, thin bedded and banded, sparsely fossiliferous

19. Shale, covered zone 
18. Argillaceous and silty limestone, interbedded; dark gray, weathers light gray with tan silty bands, fine grained, thin bedded; mostly covered slope

17. Sandy limestone, dark brownish gray, weathers about same, fine sand, medium bedded, blocky fragments, interlayered thin bioclastic sandy lenses; partly covered slope

16. Silty limestone, dark gray, weathers light gray, fine grained, medium bedded, breaks with conchoidal fracture, contains thin interbedded sandy limestone with fossil hash beds

15. Limestone, medium grayish black, weathers medium light gray, fine grained, thin to medium bedded and massive, locally argillaceous and platy; fossiliferous in more argillaceous beds, bryozoa (4 types), crinoids, FLEXARIA brachiopods and trilobites

USGS colln. 27988-PC at $12.2 \mathrm{~m}$ above base

Bryozoans, indet. (massive)

Echinoderm debris, indet.

FLEXARIA? sp.

Trilobite fragments, indet.

14. Chert and limestone, interbedded; chert medium to dark gray;, weathers medium gray; limestone dark gray, banded, weathers gray and tannish gray in more siliceous layers, slightly fossiliferous, crinoid stems

13. Argillaceous and silty limestone with chert, interbedded; limestone dark gray, weathers medium gray; chert black, weathers tannish gray; fine grained, thin bedded; platy float

12. Chert and limestone, interbedded; chert gray, weathers tannish gray, lisegang ring structure; limestone grayish-black, weathers medium gray; fine grained, medium bedded chert occurs in layers 
and lenses of irregular thickness

11. Argillaceous and silty limestones, interbedded; medium gray, weather in light gray and tan bands, fine grained, thin bedded with shale intercalations less than $15 \mathrm{~cm}$ thick

10. Limestone, grayish black, weathers medium gray, more siliceous thin layers weather brownish, fine grained, thin and medium bedded; partly covered

$6.8 \quad 108.5$

9. Limestone, grayish black, weathers medium gray, more sandy beds weather tan, medium grained, thin to medium bedded, irregular chert layers in upper part, locally fossiliferous poor preservation; slope mostly covered

USGS colln. 27987 at $12.3 \mathrm{~m}$

Bryozoans, indet.

Echinoderm debris, indet.

Chonetid brachiopods, indet.

FLEXARIA? sp.

8. Shale and siliceous limestone, interbedded; shale medium dark gray, more siliceous beds weather tan, calcareous beds weather light gray, fine grained, thin bedded to fissile; covered slope

7. Argillaceous limestone, medium gray, weathers mottled medium light gray, fine grained, thin bedded, sparsely fossiliferous locally, bellerophontids and brachiopods, indet.; blocky and platy float

6. Limestone, grayish black, weathers medium gray; fine grained, thin bedded; siliceous zones weather brownish

5. Limestone, dark gray, weathers medium to dark gray, fine grained, medium bedded, massive outcrops

4. Silty limestone and sandy limestone, interbedded; silty limestone dark gray, weathers brownish tan; fine to medium grained, thin beds 0.3 to $0.6 \mathrm{~m}$ 
thick; platy, silty, and blocky sandy limestone float

$4.7 \quad 42.5$

3. Limestone and argillaceous limestone, interbedded;

gray black, weathers light gray; fine grained, thin

bedded to platy; banded, more laminar above

$16.1 \mathrm{~m}$; broken fossils in float; mostly covered

slope

$15.5 \quad 37.8$

2. Siltstone and chert, medium gray, weathers light

brown to tan, platy at base, becomes laminar and

blocky at top; nodular cherty limestone and chert interbedded, thin bedded; $2.4 \mathrm{~m}$ cliffy outcrop, at base; at top, brown-weathered chert shows liesegang structure

1. Cherty limestone, dark gray, weathers medium gray black chert zones weather brownish gray, fine to medium grained, $5 \mathrm{~cm}$ to $0.6 \mathrm{~m}$ thin to massive cliffforming bed, banded appearance, fragmental belleroophontids, indet.; blocky float

Total thickness of the Mercur Member measured

Conformable contact

Long Trail Shale, middle member of the Great Blue Limestone 


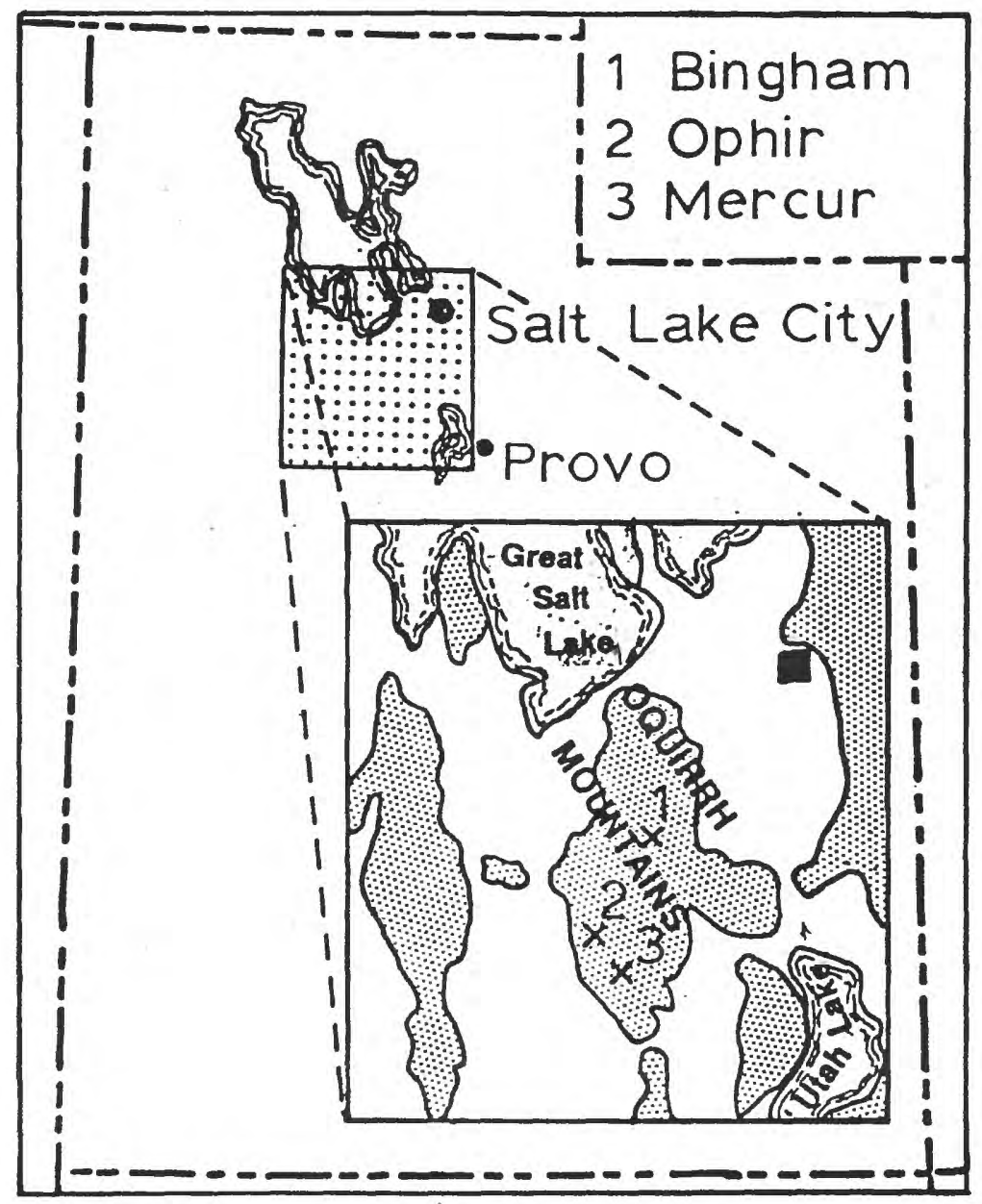

Figure 1. Index map showing the location of the Bingham, Ophir, and Mercur mining districts in the southern Oquirrh Mountains, Utah 


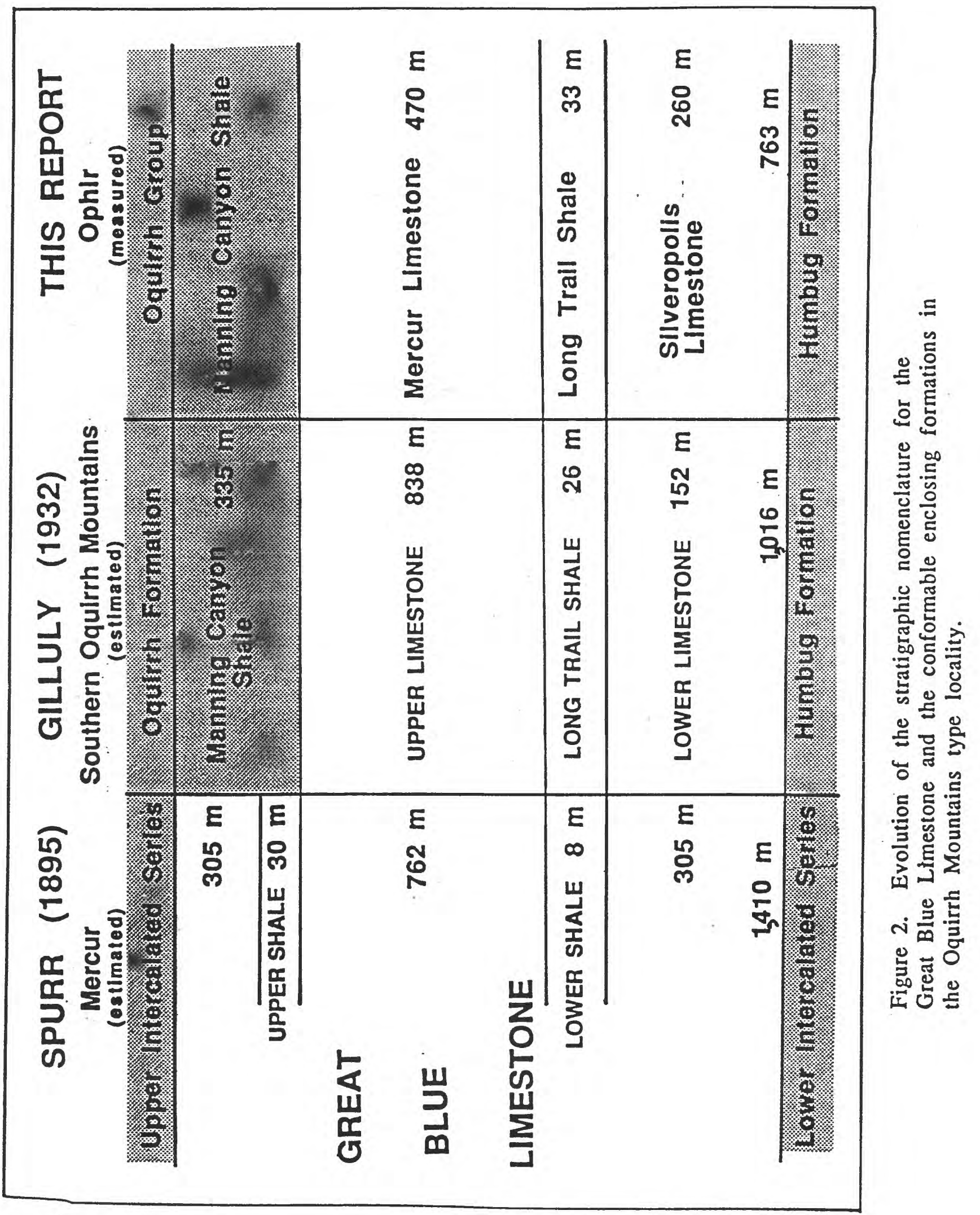




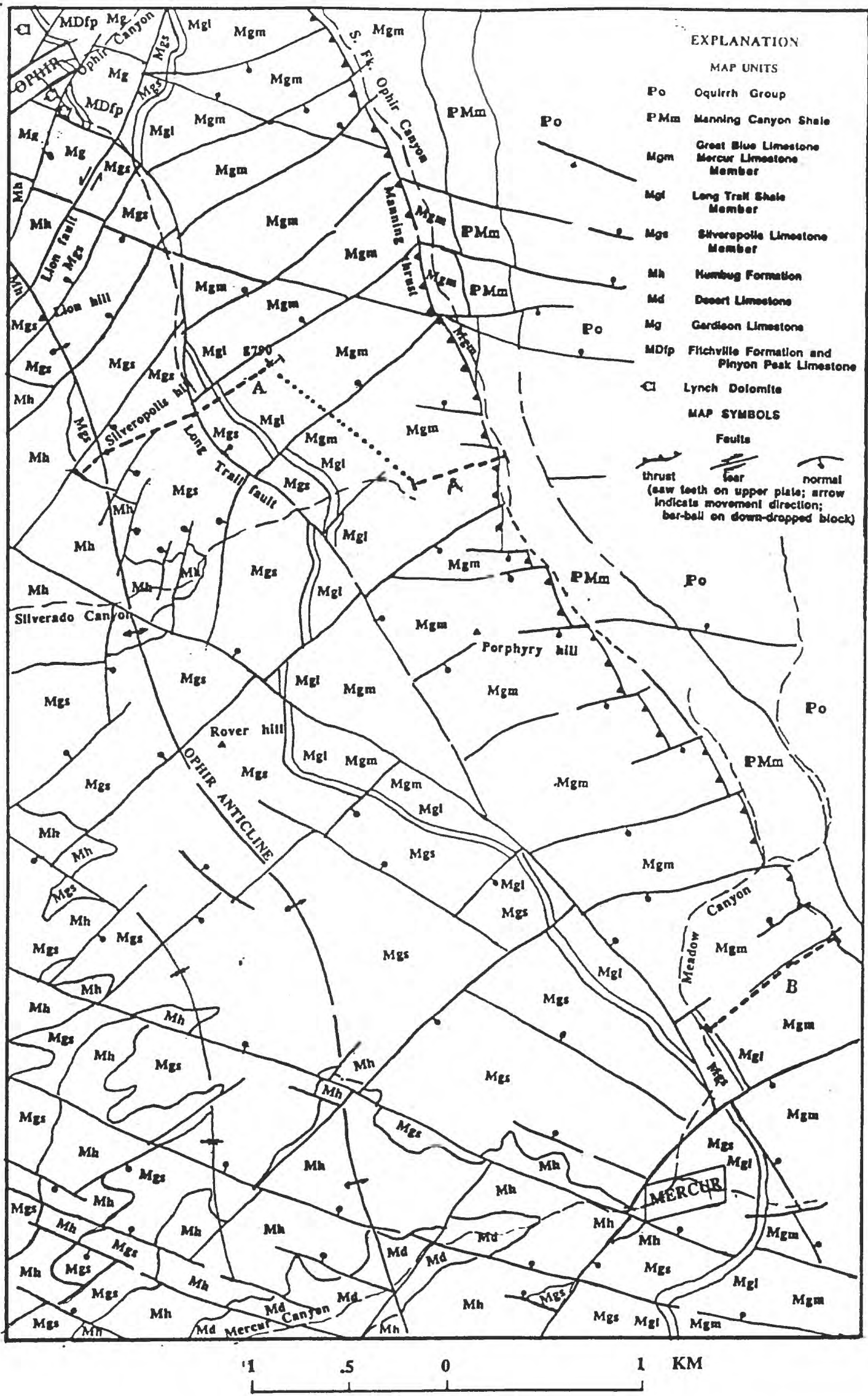

Figure 3. Geologic setting in the Bingham nappe in the southern Oquirrh Mountains, Utah, and the locations of the Great Blue Limestone type and reference measured sections (shown as the heavy dashed lines A amd B). 


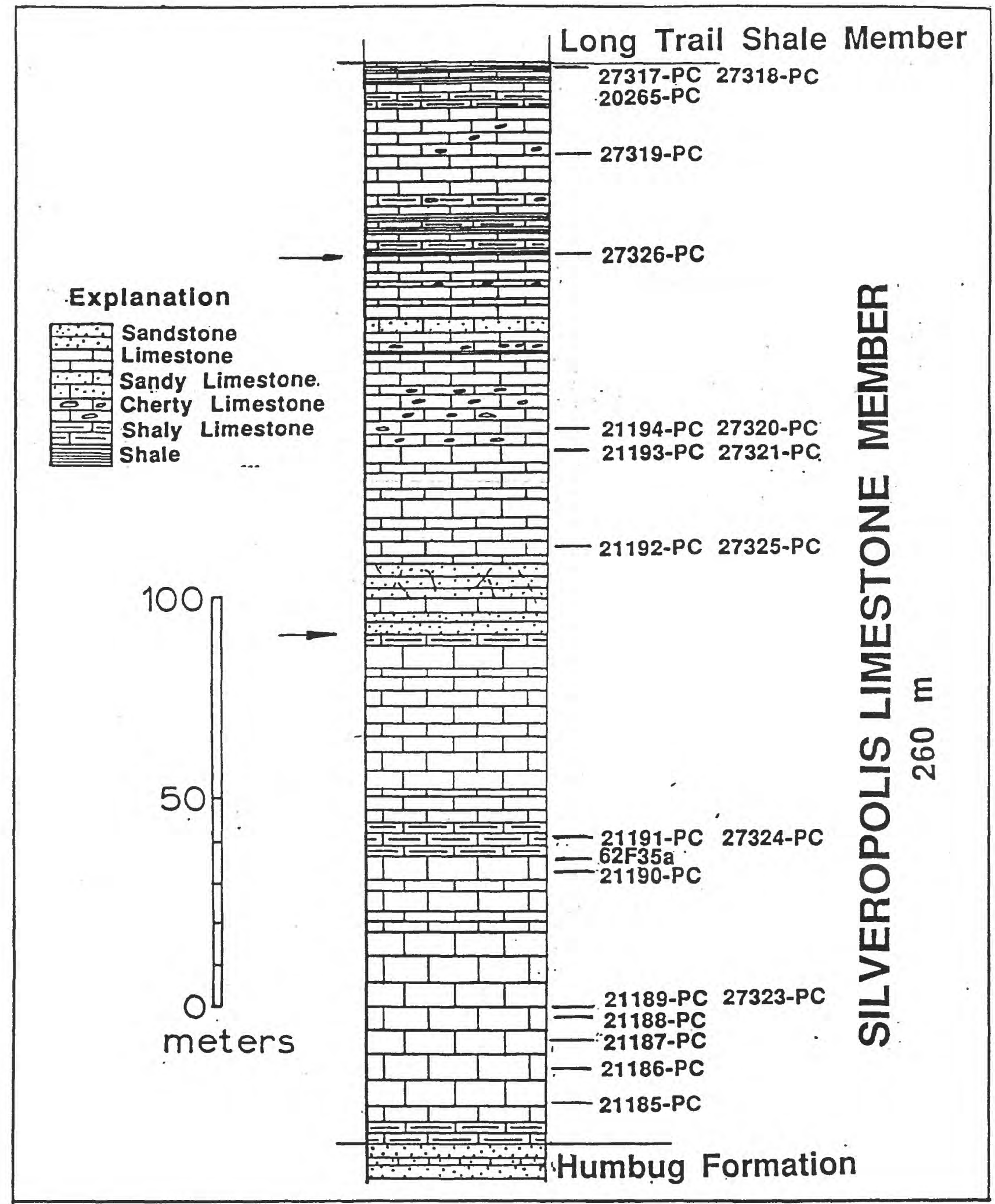

Figure 4. Diagrammatic stratigraphic section of the Silveropolis limestone member of the Great Blue Limestone near Ophir, Utah. Arrows on the left side separate three typical conformable subunits described in the text. Numbers on the right side indicate the location of USGS fossil collections described in the appendix. 


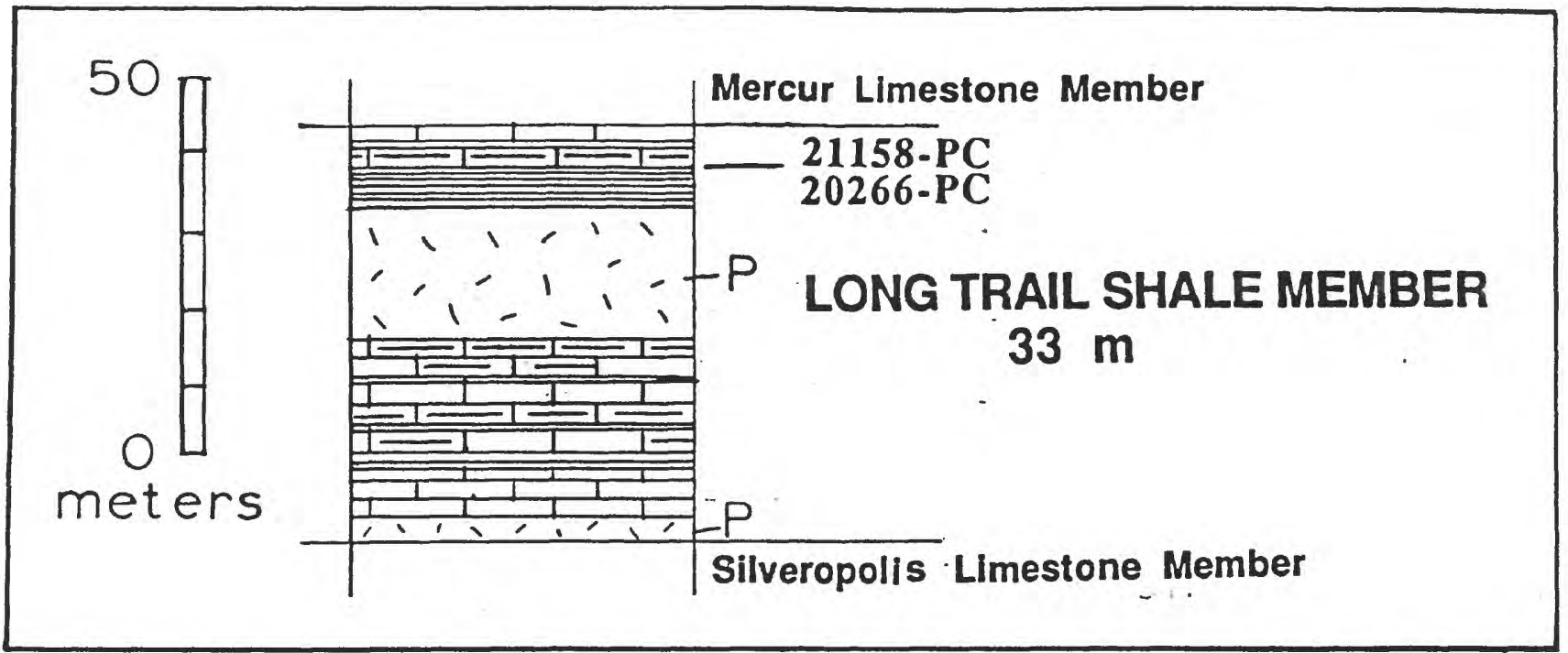

Figure 5. Diagrammatic stratigraphic section of the Long Trail Shale (member) of the Great Blue Limestone near Ophir, Utah. Numbers on the right side indicate the location of USGS fossil collections described in the appendix. 


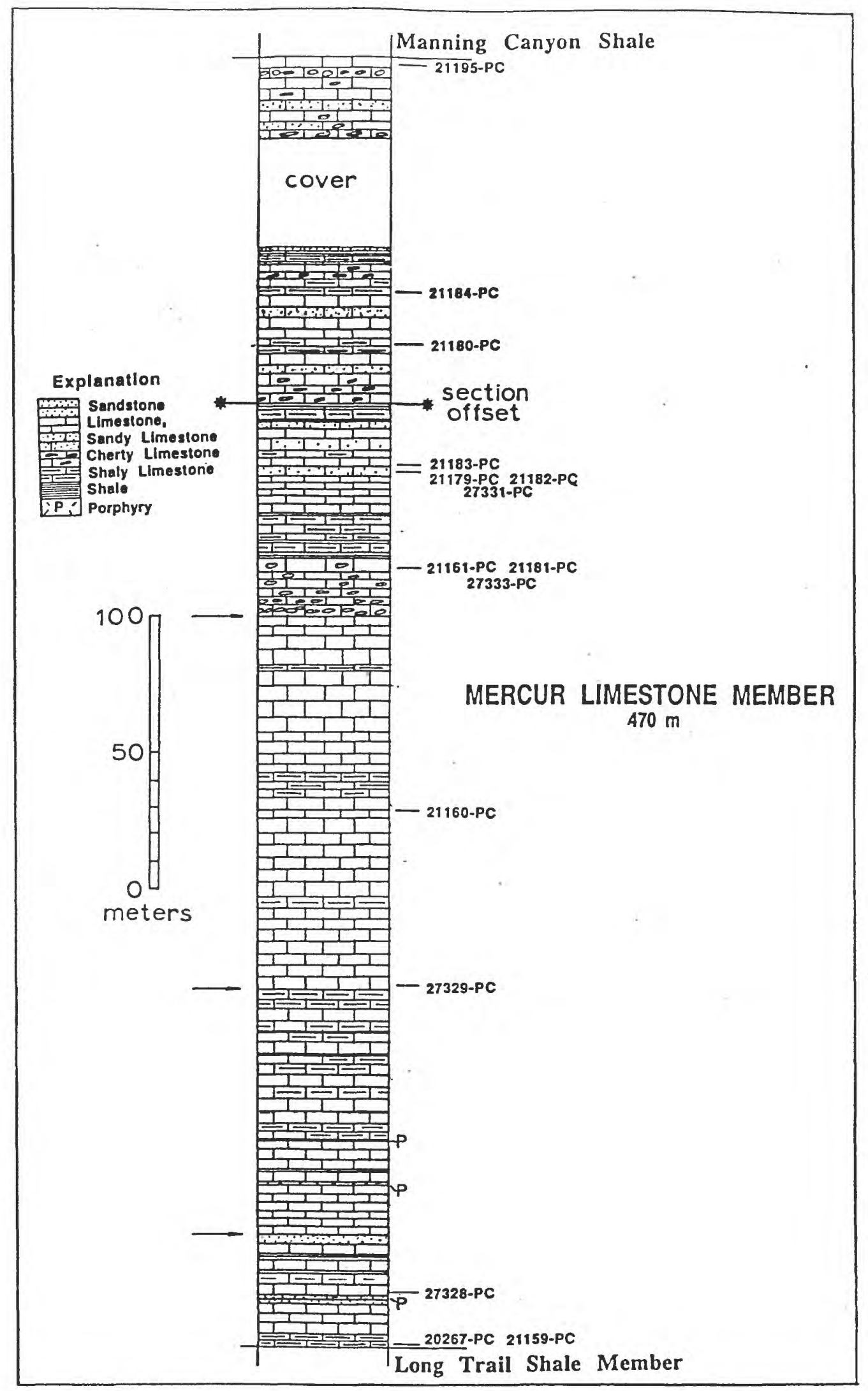

Figure 6. Diagrammatic stratigraphic section of the Mercur limestone member of the Great BLue Limestone near Ophir, Utah. Arrows on the left side separate four typical conformable subunits described in the text. Numbers on the right side indicate the location of USGS fossil collections described in the appendix. 
Great Blue Limestone

Ophir, Utah

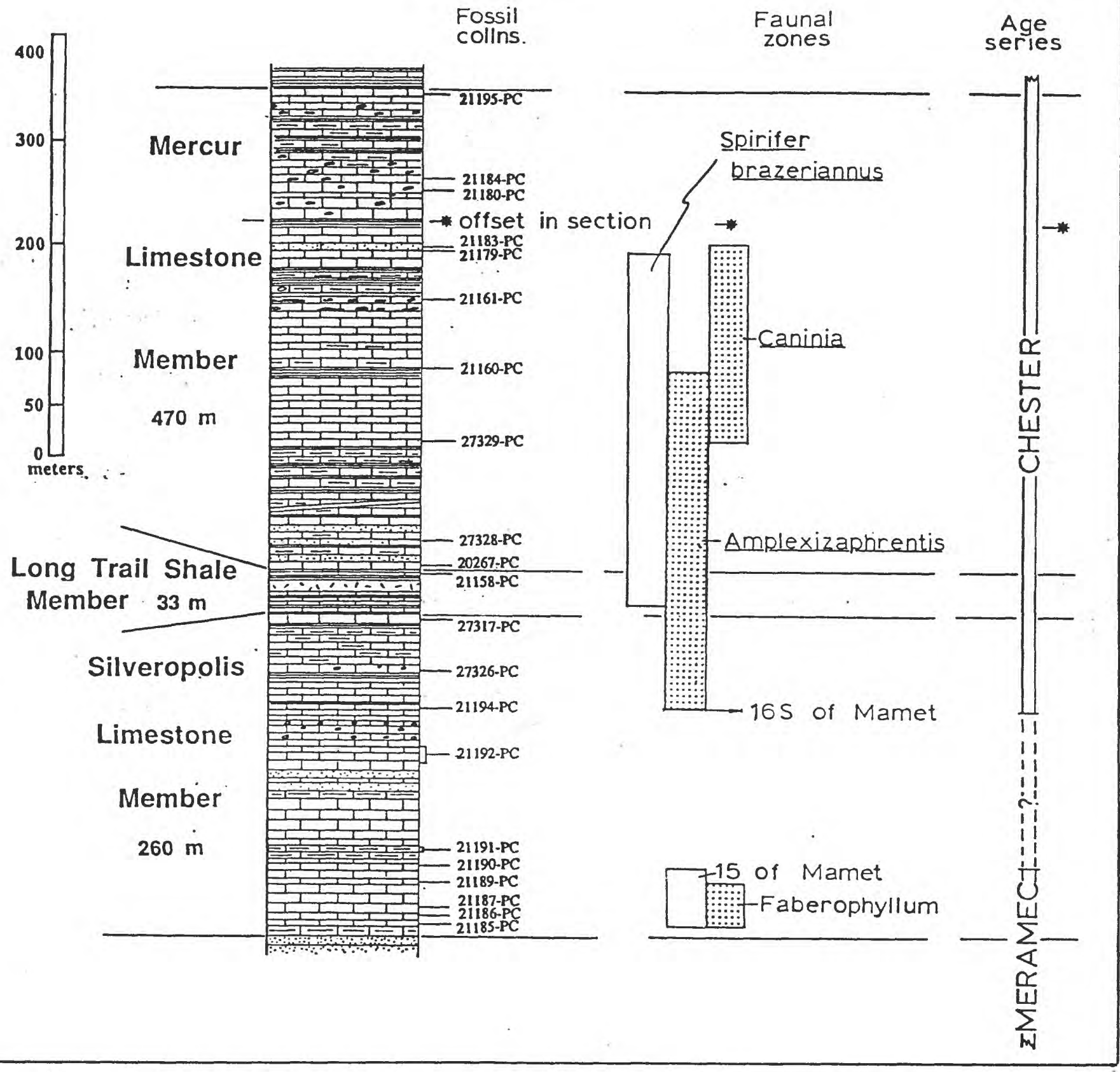

Figure 7 , Diagrammatic stratigraphic section of the Mercur limestone member of the Great BLue Limestone near Ophir, Utah. Arrows on the left side separate four typical conformable subunits described in the text. Numbers on the right side indicate the location of USGS fossil collections described in the appendix. 

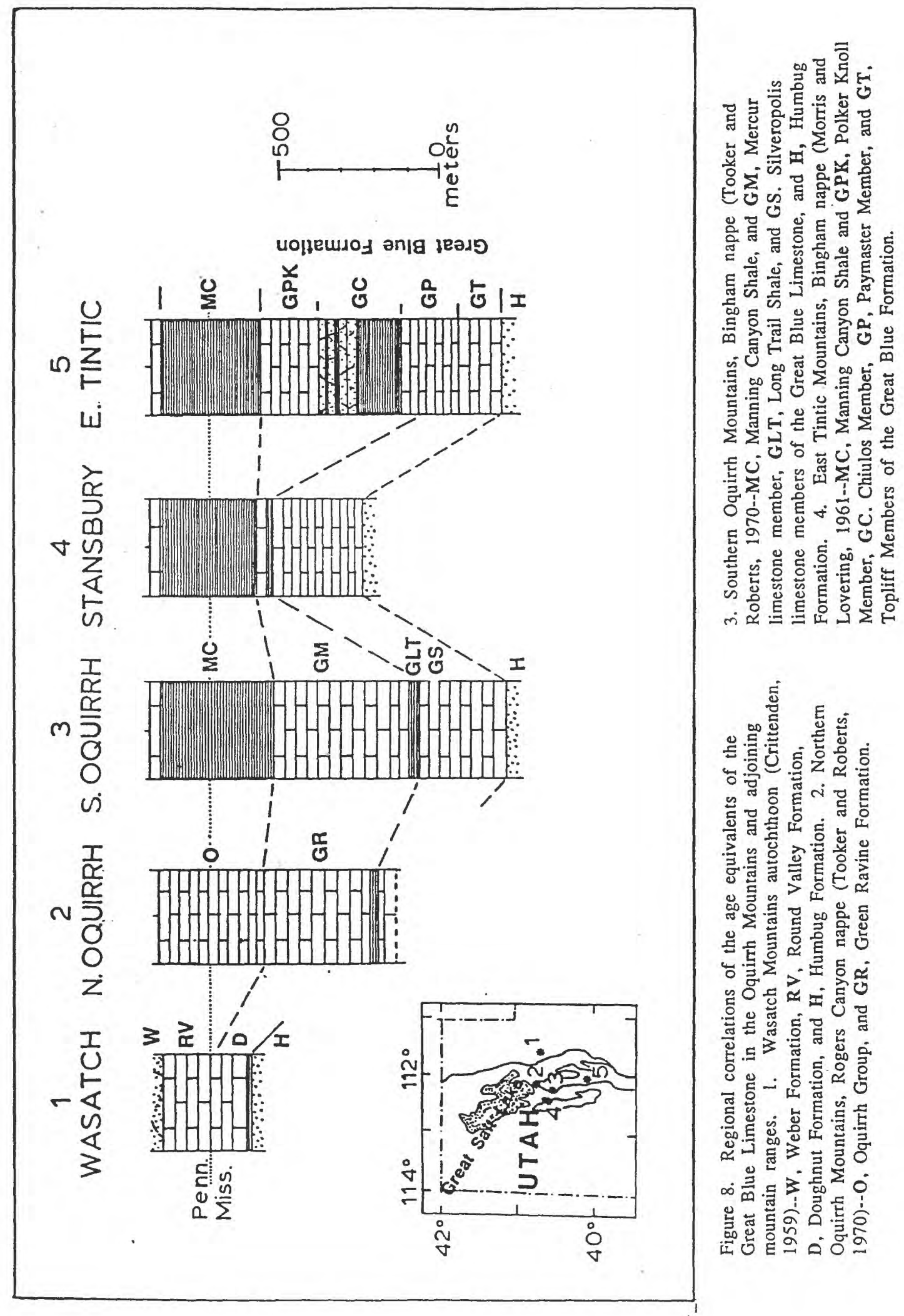